\title{
Effect of Biodiesel Blends on the Transient Performance of Compression Ignition Engines
}

\author{
Belachew Cekene Tesfa, Rakesh Mishra * and Aliyu M. Aliyu (D)
}

School of Computing and Engineering, University of Huddersfield, Queensgate, Huddersfield HD1 3DH, UK; Belachewmu@yahoo.com (B.C.T.); a.m.aliyu@hud.ac.uk (A.M.A.)

* Correspondence: r.mishra@hud.ac.uk

Citation: Tesfa, B.C.; Mishra, R.; Aliyu, A.M. Effect of Biodiesel Blends on the Transient Performance of Compression Ignition Engines. Energies 2021, 14, 5416. https:// doi.org/10.3390/en14175416

Academic Editor: Robert Černý

Received: 23 July 2021

Accepted: 26 August 2021

Published: 31 August 2021

Publisher's Note: MDPI stays neutral with regard to jurisdictional claims in published maps and institutional affiliations.

Copyright: (c) 2021 by the authors. Licensee MDPI, Basel, Switzerland. This article is an open access article distributed under the terms and conditions of the Creative Commons Attribution (CC BY) license (https:// creativecommons.org/licenses/by/ $4.0 /)$.

\begin{abstract}
Prior to full electric conversion, internal combustion engines will still maintain a paramount position in heavy goods and earth-moving vehicles. The most promising, cleaner alternative to fossil fuels is biodiesel. While it does not require alterations in the engine design, hence no major overhaul of existing infrastructure, biodiesel is more sustainable and clean-burning than petrodiesel. Extensive research has been reported on the effect of biodiesel blends, on the operational characteristics of compression ignition (CI) engines as well as the emissions behaviour of such engines. The performance characteristics of $\mathrm{CI}$ engines under transient operational conditions with Biodiesel blends has had limited attention so far from researchers. In the present work, transient performance characteristics of a CI engine has been evaluated for various biodiesel blends and its effects on performance behaviour have been quantified. In addition, emission footprints of CI engines under various transient operational conditions have also been enumerated.
\end{abstract}

Keywords: $\mathrm{CO}_{2}$ emissions; internal combustion engines; NOx emissions; renewable energy

\section{Introduction}

Biodiesel blends are becoming increasingly popular as an alternative to conventional fossil fuels to supplement increasing worldwide energy demand [1]. This is because of their adaptability of usage within conventional engines and sustainability when compared to fossil fuels [2]. It has been widely reported that biodiesel and diesel fuels have very similar thermodynamic properties even though there are differences in physical properties such as viscosity, density and the bulk modulus [3-5]. These physical properties massively influence factors such as injection pressure and fuel pump performance. Other factors that are affected include fuel-air characteristics and injection rate. The biodiesel physical properties also influence the emissions and performance of the engine. Few works have been carried out on the effects of biodiesel fuels' physical properties on the fuel pump performance characteristics, fuel injection operation and mixing behaviour of the air/oil mixture [6-11]. The influence of viscosity of the fuel-on-fuel pump performance characteristics was investigated by Bannikov et al. [12] by testing sunflower oils and biodiesel blends. They found that the engine operated with viscous blends did not achieve its rated power. It is evident from the discussion that although various biodiesel blends can be used with conventional engines there may be variations in operational characteristics and emission behaviour because of subtle differences in the way biodiesel blends interact with the engine system as well as in the combustion mechanism.

Many authors in the past have conducted studies to determine the performance of $\mathrm{CI}$ engines using with various Biodiesel blends. Some have carried out work on the type of biodiesel and the effect of nanoparticle additives. Soudagar et al. [13] evaluated the performance and emission behaviour of a modified direct injection diesel engine fuelled with biodiesel made from the castor oil plant (Ricinus communis), which is an $80 \%$ diesel blend and their blends with strontium-zinc oxide ( $\mathrm{Sr} \mathrm{ZnO}$ ) nanoparticle additives. They reported only a small increase in NOx emissions for all the nano-blended fuels studied. 
Khan et al. [14] reported a study that used a blend of biodiesel made from the Fennel flower plant, diesel, n-butanol, and graphene oxide nanoparticles. This was to improve the combustion characteristics and decrease the emissions from a toroidal-type direct injection diesel engine. The authors found that $90 \mathrm{ppm}$ of graphene oxide nanoparticles and 10\% n-butanol in Fennel flower biodiesel gives similar performance levels as diesel fuel. Furthermore, they reported that the nano-particle-impregnated fuel blend enhanced the brake thermal efficiency and reduced the brake-specific fuel consumption of the engine.

Other investigators have reported that engines running with blends of biodiesel result in improvements in injection timing. Furthermore, the onset of combustion is enhanced as the blends' biodiesel content rises [15-17]. Lately, Gumus [17] presented a study detailing the burning and heat emancipation properties of biodiesel used in an engine using directinjection compression ignition. Experiments were performed for different biodiesel blends such that pressure measurements within the combustion cylinder were carried out. Using this information, the duration of combustion, cumulative heat release rate amongst other parameters were computed. They concluded that biodiesel combustion characteristics did not significantly deviate from those of diesel in the engine tested. Nevertheless, as the amount of biodiesel in the blend rises, it was observed that shorter ignition delays occurred as well as and shorter premixed stage durations [18-22]. We note that studies on combustion characteristics of biodiesel blends are inconsistent as there is a lack of systematic investigation to quantify the interrelationship between biodiesel's physical and combustion characteristics. More work is required to understand the combustion process so that the performance and emission characteristics of engines running with biodiesel blends are improved.

The characteristics of $\mathrm{CI}$ engines using various blends of biodiesel in steady state conditions of operation are widely given in previous works [23-28]. The key engine performance indicators with biodiesel blends have been reasonably well studied. These include brake power, specific fuel consumption, thermal efficiency, engine speed, engine load, and engine types. Conversely, there are limited published literature on systematically studying engine performance parameters with biodiesel and its blends during transient operating conditions. Indeed, most of the works present performance under steady-state operations [29-32]. Transient operation is mainly observed during urban driving conditions due to the 'stop and go' nature of vehicular traffic. Detailed research outcomes are also available in the literature with varying degrees of clarity on the emission characteristics of $\mathrm{CI}$ engines operating with biodiesel during steady-state operations. However, transient $\mathrm{CI}$ engine behaviour has not been widely studied. In this study, we therefore investigate the practicality of biodiesel and biodiesel blends under transient operating situations. In addition, we carry out a detailed analysis of the effect of biodiesel blending ratio, the influence of load variation and engine speed on engine emissions.

\section{CI Engine and Test Bed Facilities}

The tests in a CI engine were carried out within the Advanced Automotive Laboratory, at the University of Huddersfield. The facility possesses a transient testing unit which has a $200 \mathrm{~kW}$ AC Dynamometer. It also has a 4-Quadrant Regenerative Drive unit possessing motoring and absorbing capability. Installed are an in-line torque meter, various speed sensors, thermocouples, pressure transducers, air flow metres, and fuel flow metres. The $\mathrm{CI}$ engine is direct injection with four cylinders, four strokes, and is turbo-charged. The bore is $103 \mathrm{~mm}$ while the stroke is $132 \mathrm{~mm}$, and it has 4.4 litres of engine displacement. Furthermore, the compression ratio is 18.3. The detailed characteristics of the engine are given in Table 1 while the layout of the experimental set up and associated instrumentation are depicted in Figure 1. The engine was wholly instrumented, the steady and transient cycles were programmed with the CADET software integrated with the engine. 
Table 1. Characteristics of the test engine.

\begin{tabular}{cc}
\hline Engine Type & Turbo Charged Diesel Engine \\
\hline Number of cylinders & 4 \\
Bore & $103 \mathrm{~mm}$ \\
Stroke & $132 \mathrm{~mm}$ \\
Diameter of inlet valve & $36.5 \mathrm{~mm}$ \\
Diameter of exhaust valve & $33.2 \mathrm{~mm}$ \\
Compression ratio & 18.3 \\
Number of valves & 16 \\
Method of injection & Direct injection \\
Engine displacement & 4.399 litre \\
Cooling system & Water \\
Recommended speed & $850 \mathrm{rpm}$ \\
Max power & $74.2 \mathrm{~kW}$ 2200 rpm \\
\hline
\end{tabular}

For acquiring accurate and repeatable biodiesel engine test data for performance evaluation, state-of-the-art instrumentation was installed as shown in the figure. The main quantities measured are the combustion pressure and temperature, engine speed, load, crank angle, air and fuel flow rates and TDC position. Each signal was conditioned prior to connection to the data acquisition system, and it was necessary to amplify some to increase the resolution of low-level signals as well as differentiate from background noise. Furthermore, signal amplification enabled the highest conditioned signals' voltage range to be equal to the highest analogue-to digital converter (ADC) input range.

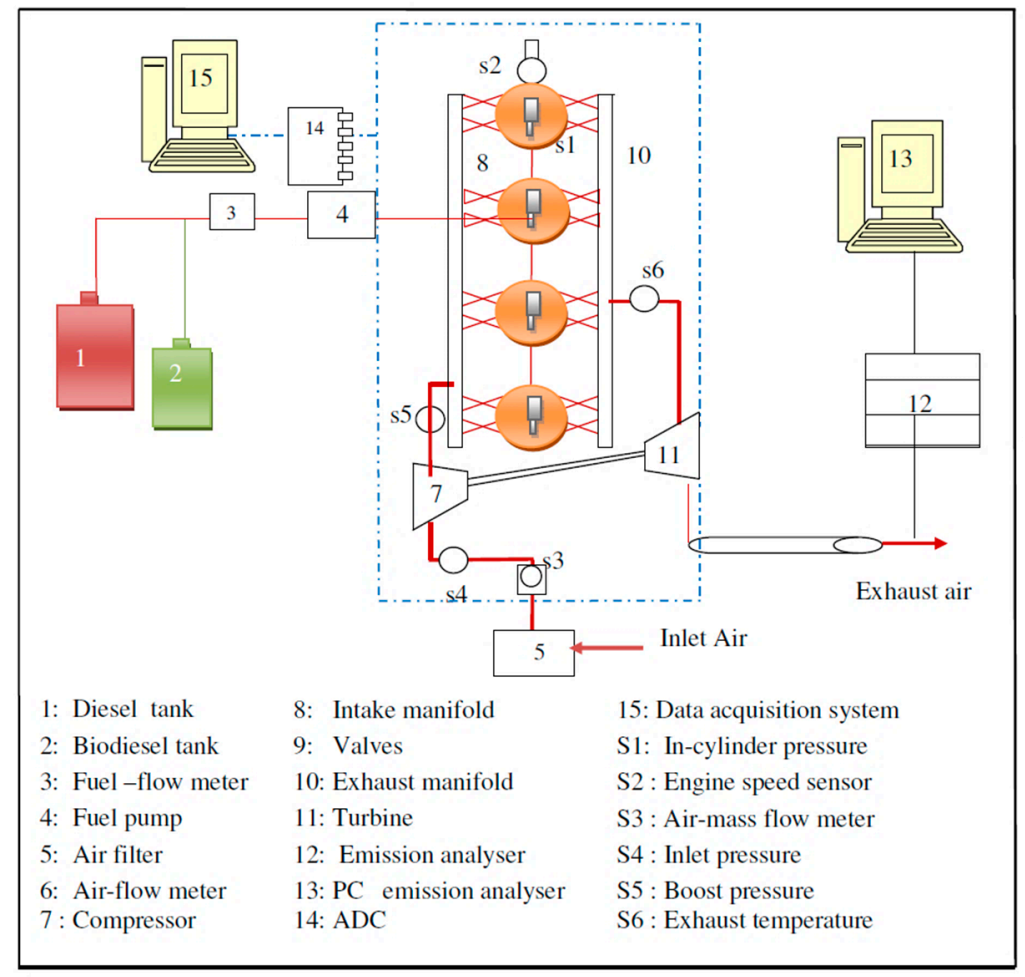

Figure 1. Experimental engine test facility layout.

To measure gaseous emissions, a gas test bench (HORIBA EXSA-15008) was used and its sample line was connected straight to the engine's exhaust pipe which was heated to sustain a wall temperature of approximately $191.0^{\circ} \mathrm{C}$ to avoid hydrocarbon condensation within the line. Additionally, the insulated line was further added to from the exhaust pipe to the analysers. All the emission analysers (i.e., for NOx, $\mathrm{CO}, \mathrm{CO}_{2}$ and THC) were placed on one workbench, but each has a different measurement principle, as shown in Table 2. 
Table 2. The emission analyser type and measuring range.

\begin{tabular}{cccc}
\hline Emission Type & Analyser Type & Measuring Range & Uncertainty \\
\hline $\mathrm{CO}$ & non-dispersive infrared (NDIR) & $0-2000 \mathrm{ppm}$ & $\pm 2 \%$ \\
$\mathrm{CO}_{2}$ & non-dispersive infrared (NDIR) & $0-100 \%$ & $\pm 2 \%$ \\
$\mathrm{NOx}$ & heated chemiluminescent detector (HCLD) & $0-5000 \mathrm{ppm}$ & $\pm 2 \%$ \\
$\mathrm{THC}$ & heated flame ionisation detector (HFID) & $0-100 \mathrm{ppm}$ & $\pm 1 \%$ \\
$\mathrm{O}_{2}$ & paramagnetic detector & $0-25 \%$ & $\pm 1 \%$ \\
\hline
\end{tabular}

\subsection{Details of Biodiesel and Petro Diesel Fuels Used in the Investigation}

For the investigations carried out, three biodiesels (made from corn oil, rapeseed oil, and waste oil) were purchased locally and used for testing and analysis. The production of biodiesel is via the transesterification of the oil with and alcohol usually methanol. Conventional petroleum diesel fuel was obtained from a local filling station and was red in appearance. The same sample was used in all tests for combustion, performance, and emissions evaluation. The red coloured diesel was selected because of the low fuel tax for it for use in off-road engines and it was then blended with diesel on a volumetric basis at 5 , $10,20,50,75$ and $100 \%$. A total of 6 samples were prepared for every biodiesel used. In all, 19 samples were prepared and utilised in viscosity and density characterisation tests.

\subsection{Calibration of Instruments}

Prior to experiments, the various sensors and instrumentation were calibrated using data acquisition software and hardware. Readings were taken to cover the required operating ranges. The gain and offset values for each individual signal were then determined. For calibrating the Kistler in-cylinder pressure transducer, a known pressure was applied to the sensor and the response voltage was measured from the charge amplifier. As the Kistler pressure transducer (Kitsler type) only generates a signal once, there was a change in pressure, during the exhaust stroke. The reference pressure used was atmospheric, and the resulting offset was automatically applied by writing it into the software used for data acquisition. A portable pressure instrument (model: Druck DP-601) was used to calibrate the pressure transducers within an uncertainty level of $\pm 0.1 \%$. The appropriate gain and offset values for each transducer were determined and used to calculate the pressure from the raw voltage signals acquired. An accuracy of $\pm 0.1 \%$ was determined for the dead weight system and all emissions measurement equipment were calibrated daily before experiments were carried out according to the emission measurement procedures. The experiments were performed over a wide range of biodiesel feed sources, blend types and steady/transient test modes.

\section{Results and Discussion}

In this section, the results obtained from the in-depth study carried out to quantify biodiesel effects on engine's transient performance are discussed. Synthetic speed and torque test cycles were developed for studying the effect of transients in CI engine performance as well as the engine's emission characteristics. While the results of steady-state testing have been widely reported in the literature [33-36], transients have not been studied as much. Here, the transient behaviour of $\mathrm{CI}$ engines was independently investigated during acceleration and deceleration for both engine speed and torque produced. These are shown in Figures 2 and 3, respectively. Figure 2 a shows the profile of engine speed for a torque of $420 \mathrm{Nm}$. Prior to data collection, about 10 minutes was left for the engine to first stabilise. During transient engine tests, previous authors have reported the normal acceleration duration to be in the range of 1-10 s [16]. The steady and transient duration used in the current tests are 17 and $8 \mathrm{~s}$, respectively. Ultimately, the engine was run at $1500 \mathrm{rpm}$ for $35 \mathrm{~s}$ under steady-state conditions. The deceleration of the $\mathrm{CI}$ engine operation is shown in Figure $2 \mathrm{~b}$. In summary, the engine was run steadily for $17 \mathrm{~s}$, then decelerated for $8 \mathrm{~s}$ and then run for another $35 \mathrm{~s}$ under steady-state conditions. 


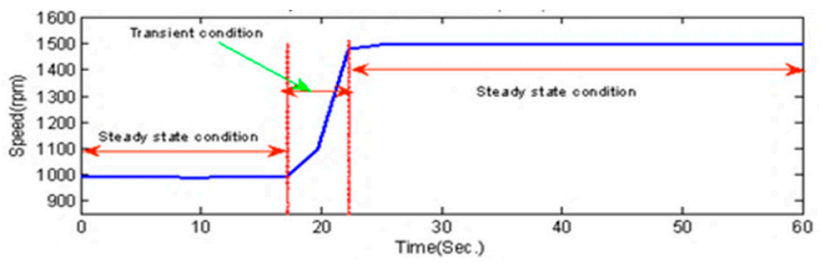

(a)

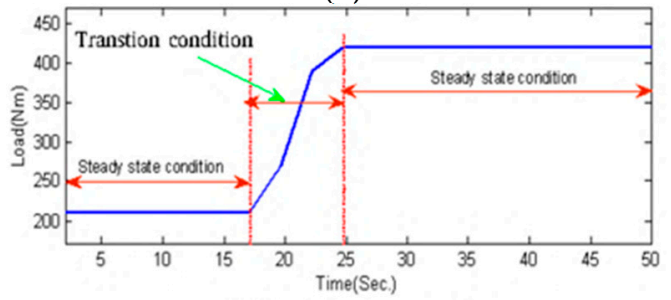

(c)

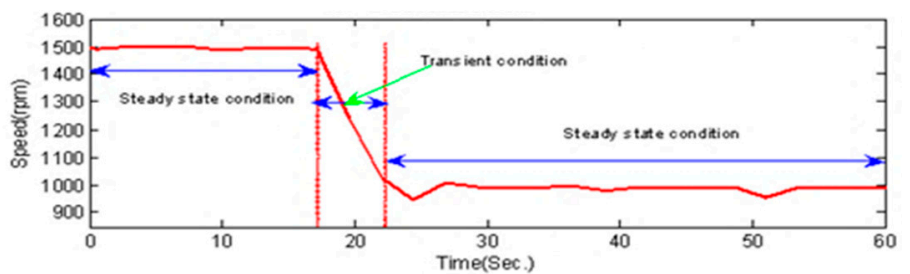

(b)

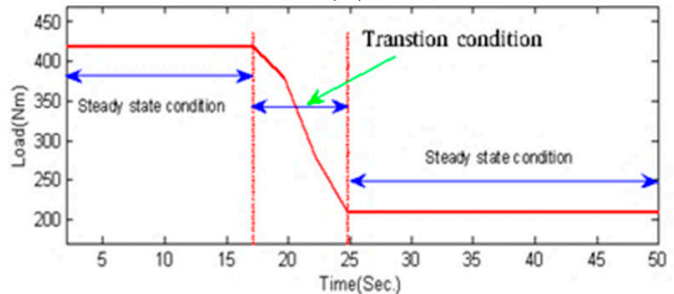

(d)

Figure 2. Speed transient profiles. (a) Acceleration at 1000 to $1500 \mathrm{rpm}$; (b) deceleration at 1500 to $1000 \mathrm{rpm}$. Torque transition profiles for (c) positive torque transition from $210-420 \mathrm{~N}$ and (d) negative transition from 420-210 Nm.
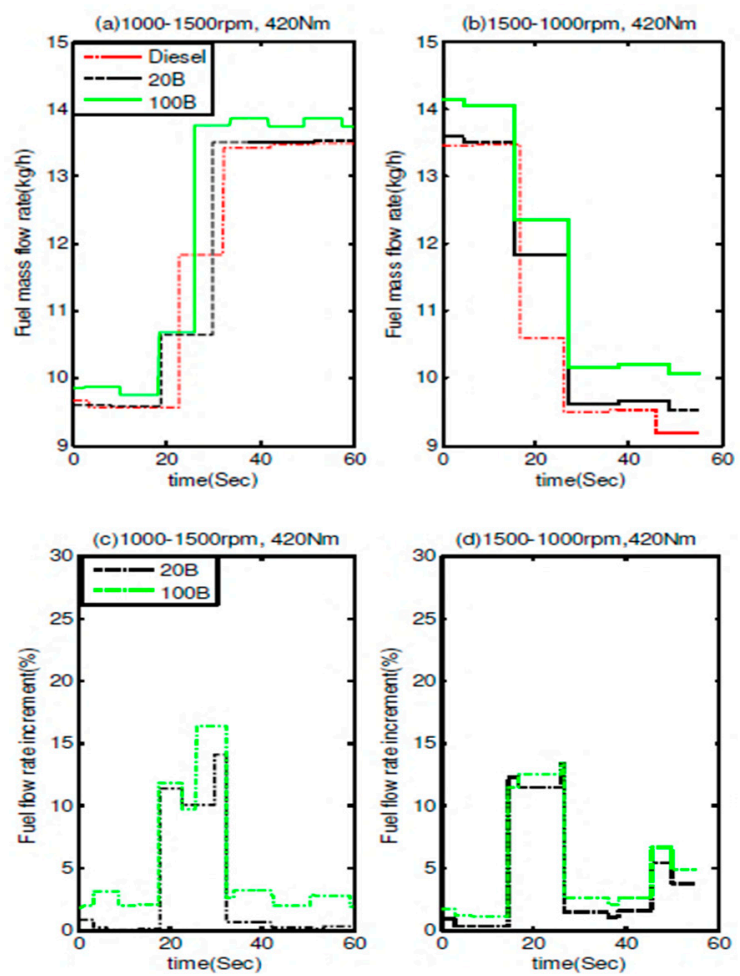

Figure 3. Time response during speed transients at $420 \mathrm{Nm}$ of fuel flow rate for the CI with biodiesel with (a) positive and (b) negative speed transient. Fuel flow rate percentage increment with biodiesel blends for (c) positive and (d) negative speed transient. All are at engine loads of $420 \mathrm{Nm}$.

A shorter steady pre-transient engine operation was used than the steady posttransient conditions. The reason for doing this was to investigate the effects of transient operation on the subsequent steady state operation. Figure $2 \mathrm{c}$, d show the positive and negative torque transition profiles at an engine speed of $1500 \mathrm{rpm}$. The engine was operated for a time period of $17 \mathrm{~s}$ in steady state operation conditions. It was afterwards run for $8 \mathrm{~s}$ in transition mode while the torque changed from $210 \mathrm{Nm}$ to $420 \mathrm{Nm}$. Ultimately, the engine was run at $420 \mathrm{Nm}$ for $35 \mathrm{~s}$. This is shown in Figure 2c. Correspondingly, Figure 2d shows the negative torque transition of the engine. In the negative torque transition case, the time segment and torque values have similarities with the positive torque transition condition. 


\subsection{Performance Characteristics during Transient Operation}

The rate of fuel consumption, the temperature of the engine exhaust and pressure in the cylinders were investigated for understanding the influence of biodiesel blends on the performance of $\mathrm{CI}$ engine performance during transient operation. Since the rate of fuel consumption is more sensitive than the break specific fuel consumption (BSFC), the former was chosen to examine the effect of blend on engine performance. The exhaust gas temperature exhibited a high sensitivity to dynamic phenomena and ease in its measurement. As such, it is usually used for diagnosing combustion performance of the fuel and for monitoring combustion anomalies [19,20], in the design and operation of exhaust gas recirculation (EGR) [19], as well as for prediction using emission models [22]. Additionally, to obtain detailed information about the combustion process, the in-cylinder pressure values were also monitored.

\subsubsection{Fuel Consumption Rate}

The fuel flow rate was quantified using the fuel measurement instrumentation (FMS-1000, which measures on a gravimetric basis). Figure 3 depicts the biodiesel fuel flow rate under a speed transient of 1000-1500 rpm and 1500-1000 rpm at $420 \mathrm{Nm}$ load. The rate of fuel flow rises by $35 \%$ on accelerating from 1000 to $1500 \mathrm{rpm}$. Conversely, the rate of fuel flow decreases by $32.9 \%$ on decelerating the engine from 1500 to $1000 \mathrm{rpm}$. The fuel flow rate increase with acceleration is because as the engine speed is increased, the rate of charging the cylinder increases, and as a result, there is an increase in the rate of fuel flow [23,24].

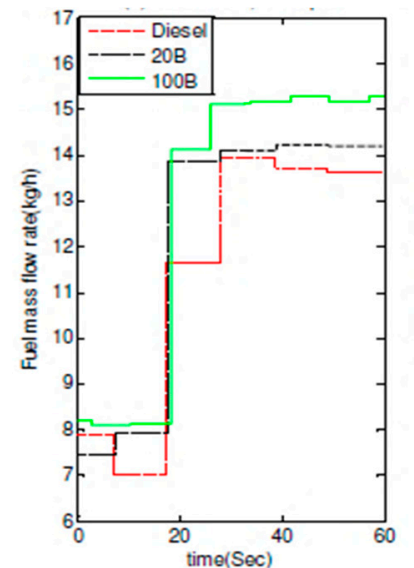

(a)

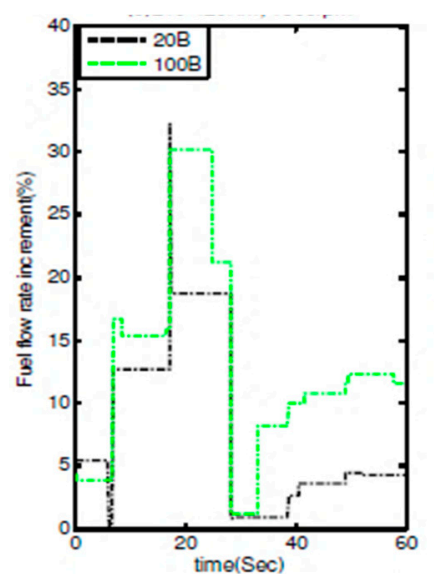

(c)

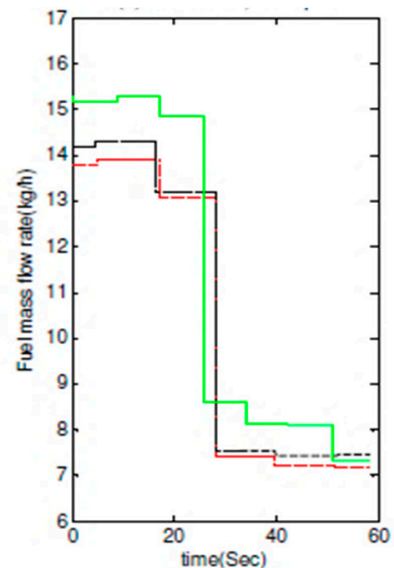

(b)

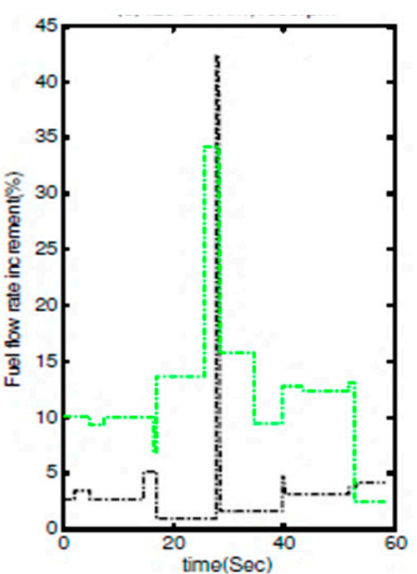

(d)

Figure 4. $(\mathbf{a}, \mathbf{b}) \mathrm{CI}$ time response during positive and negative torque transition at $420 \mathrm{Nm}$ using biodiesel and $(\mathbf{c}, \mathbf{d})$ the corresponding fuel flow rate percentage increment at positive and negative torque transition respectively. 
Additionally, while accelerating, the horsepower due to friction increases due to a decrease in efficiency for maintaining a constant torque output. This leads to a rise in the rate of fuel consumption [23]. In Figure $3 c$, d it is shown that the fuel consumption of the engine operating with $100 \mathrm{~B}$ is higher than the efficiency of diesel by $16 \%$ while accelerating and is $14 \%$ higher during the deceleration transient operation. This occurred because of the influence of the lower biodiesel heating value. This lower value is less than that of conventional diesel by approximately $12 \%$. In the past, investigators [26-32] have also reported similar fuel consumption trends based on discrete engine speed tests.

Figure 4 shows the influence of operating at torque transient conditions on the rate of diesel fuel consumption along with two blends 20B and 100B. The fuel consumption rises by $31 \%$ while the torque transition increased from 210 to $420 \mathrm{Nm}$ (i.e., positive torque transition) running at $1500 \mathrm{rpm}$. Correspondingly, the fuel consumption is reduced by $34 \%$ as the torque decreases from 420 to $210 \mathrm{Nm}$ (i.e., negative torque transition). This is because of an increase in the fuel injection required to reach the higher total energy output for a certain engine speed. It can be seen in Figure $4 \mathrm{c}, \mathrm{d}$ that comparing the diesel and biodiesel blends' consumption rates in the $\mathrm{CI}$ engine resulted in higher fuel consumption by the latter rate by $17 \%$ and $15 \%$ for the positive and negative torque transitions, respectively.

\subsubsection{Exhaust Gas Temperature}

Figure 5 presents the temperatures of the exhaust gas obtained from the diesel tests and those of 20B and 100B during a speed transient of 1000-1500 rpm and 1500-1000 rpm. The engine load is $420 \mathrm{Nm}$. The graph shows there is no significant difference in temperature for the diesel and biodiesel blends' exhaust gases in both acceleration and deceleration conditions. Both conditions exhibit a maximum difference of $2 \%$ between the engine exhaust gas temperature with diesel and biodiesel blends. During acceleration, the exhaust temperature rises from around 600 to $710 \mathrm{~K}$. conversely, during deceleration, the exhaust temperature falls from around 710 to $630 \mathrm{~K}$. This is because as when the engine accelerates from $1000 \mathrm{rpm}$ to $1500 \mathrm{rpm}$, the quantity of fuel introduced into the cylinder also increases to keep a fixed engine torque output. Hence, as expected, the exhaust gas temperatures increase because of burning the fuels.

During deceleration from 1500 to $1000 \mathrm{rpm}$ engine speed, the reverse process occurs in the cylinder. Figure 6 shows the consequences of the torque transition on exhaust gas temperature. The figure shows results of the engine operating with diesel, as well as blends $20 \mathrm{~B}$ and 100B. Figure $6 \mathrm{a}$ gives the exhaust temperature rising from 570 to $670 \mathrm{~K}$ through a positive torque transition from 210 to $420 \mathrm{Nm}$ at an engine speed of $1500 \mathrm{rpm}$. Likewise, during negative torque transition between 420 and $210 \mathrm{Nm}$, the exhaust gas temperature decreases due to a rise in the fuel required for reaching a higher overall energy input. Comparing the exhaust temperatures of the $\mathrm{CI}$ engine with diesel and biodiesel blends and diesel, Figure 6 shows that the engine running with the latter gave a 7\% increase in the temperature of the gas exhaust for the positive and negative transition torque conditions. Furthermore, the temperature of the exhaust gases rises with increasing biodiesel blend fraction. A possible reason is that as biodiesel has about $10.5 \%$ oxygen in its molecule, which facilitates total fuel combustion within the CI engine's cylinder. Hence, temperature in the cylinder rises and thus there is a corresponding increase in the temperature of the exhaust gases. 


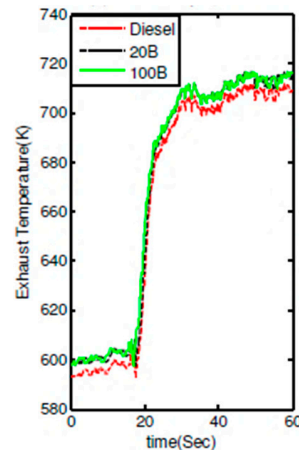

(a)

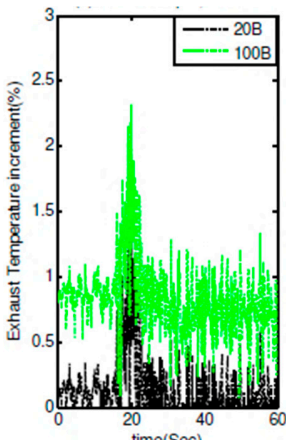

(c)

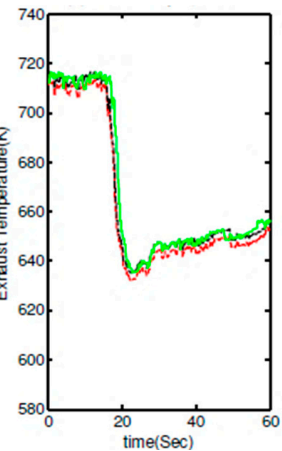

(b)

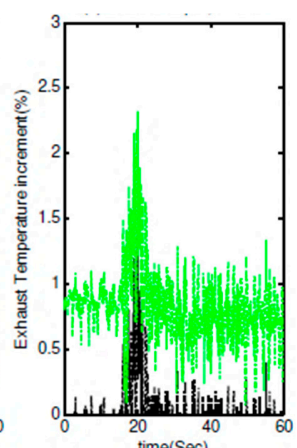

(d)

Figure 5. Exhaust temperature of the CI engine fuelled with diesel and biodiesel blends at a speed stable at $420 \mathrm{Nm} .(\mathbf{a}, \mathbf{b})$ Exhaust temperatures at positive and negative torque transients and $(\mathbf{c}, \mathbf{d})$ exhaust temperature \% increase.

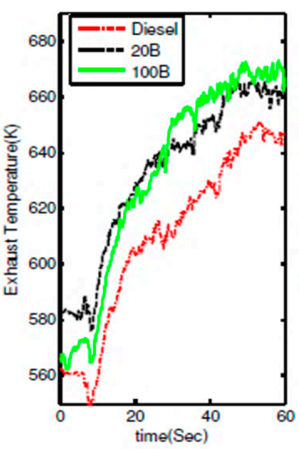

(a)

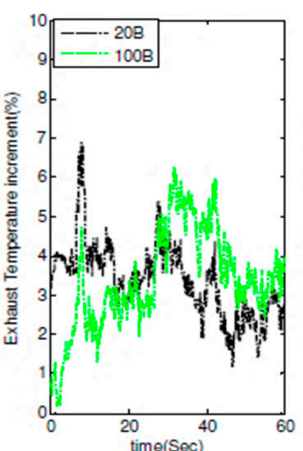

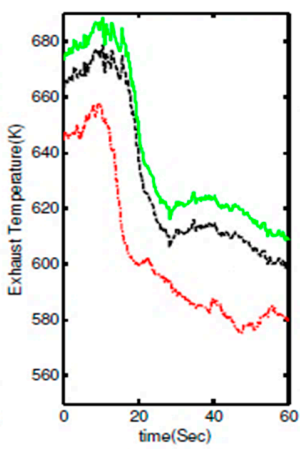

(b)

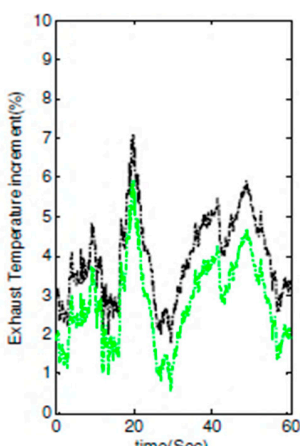

(d)

Figure 6. Time response of exhaust temperature for CI with biodiesel during (a) positive $(210-420 \mathrm{Nm}$ ) and (b) negative torque transition at $1500 \mathrm{rpm}$. Corresponding temperature percentage change at (c) positive and (d) negative torque transition. 


\subsubsection{In-Cylinder Pressure}

During the development and calibration of engines, the most valuable source of combustion information is the in-cylinder pressure. This signal provided important information for analysis of the engine behaviour. These include the heat release rate, peak pressure (and a P-V diagram can be constructed), indicated mean effective pressure, injector pressure, combustion duration, ignition delay, etc. In this section, we discuss in detail the in-cylinder pressure and the effect of fuel type. Figures 7 and 8 depict the maximum in-cylinder pressure for 4 conditions of operation. These are the increase from 1000-1500 rpm, deceleration operation from values of $1500-100 \mathrm{rpm}$, the positive torque transition from 210 to $420 \mathrm{Nm}$ as well as the negative torque transient of 420 to $210 \mathrm{Nm}$. Figure 7 presents the results of peak pressure inside the engine cylinder with diesel, blends 20B, and 100B fuels at an engine torque of $420 \mathrm{Nm}$ during the speed transition from 1000-1500 rpm.

Figure 7 a shows that the $\mathrm{CI}$ engine with $100 \mathrm{~B}$ and $20 \mathrm{~B}$ gave $15 \%$ and $7 \%$ higher incylinder peak pressures than diesel within the transient segments of operating the engine. This process is because of the total carbon molecule combustion to produce the maximum torque. It is reckoned that the main source of the increased in-cylinder peak pressure of the engine operating with biodiesel is the complex combustion process occasioned by lower biodiesel viscosity.

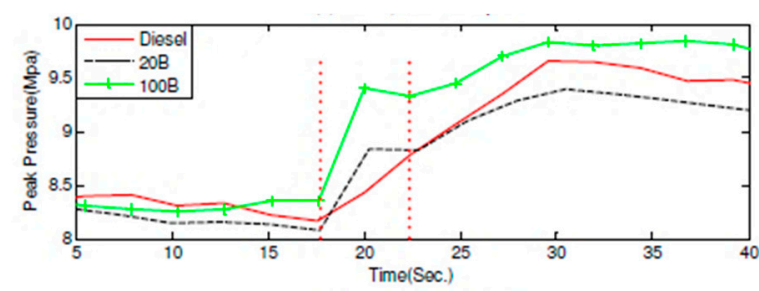

(a)

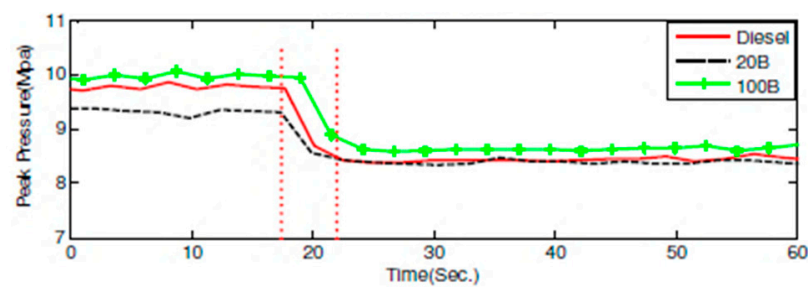

(c)

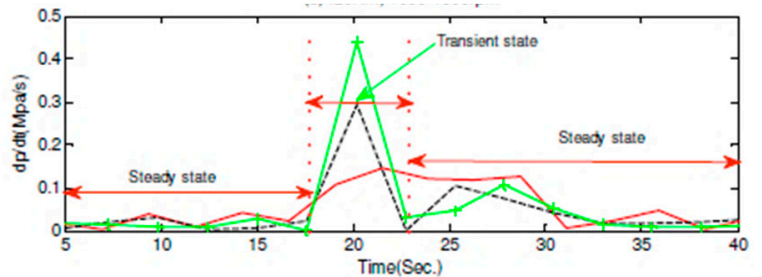

(b)

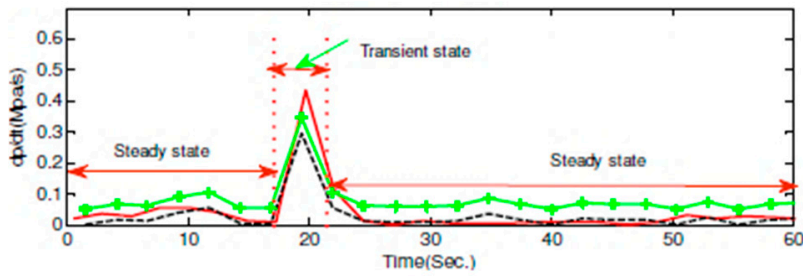

(d)

Figure 7. (a) In-cylinder peak pressure vs. time for CI engines running with different fuels during the positive speed transient and the (b) corresponding in-cylinder peak pressure at positive speed transient. (c) In-cylinder peak pressure during negative speed transient and the (d) corresponding rate of change of in-cylinder peak pressure vs. time during the negative speed transient.

Additionally, because of the presence of oxygen molecules in biodiesel, the hydrocarbons experience complete combustion. Figure $7 \mathrm{~b}$ shows that the in-cylinder pressure initially remains almost constant with time. However, because of the post-transient operation, the in-cylinder pressure change exhibited some irregular behaviour. Firstly, in the transient segment, the pressure in the cylinder reached a peak. Figure $7 \mathrm{c}$ shows that the in-cylinder peak pressure with $20 \mathrm{~B}$ and $100 \mathrm{~B}$ at an engine load of $420 \mathrm{Nm}$ at a deceleration of 1500-1000 rpm. As was with the speed transient condition, the engine operating using 100B resulted in a 5\% larger peak pressure in the engine than diesel. Figure $7 \mathrm{~d}$ shows that the in-cylinder pressure rate was nearly uniform in pre-transient as well as post-transient steady state operations. For the transient operation, biodiesel blend operated engine exhibited higher peak pressures in the cylinders than when fuelled with pure diesel. 


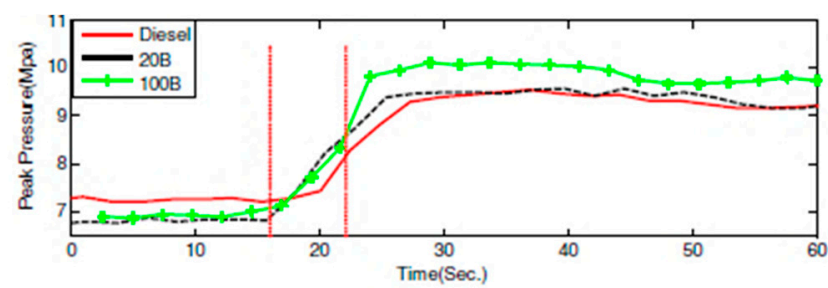

(a)

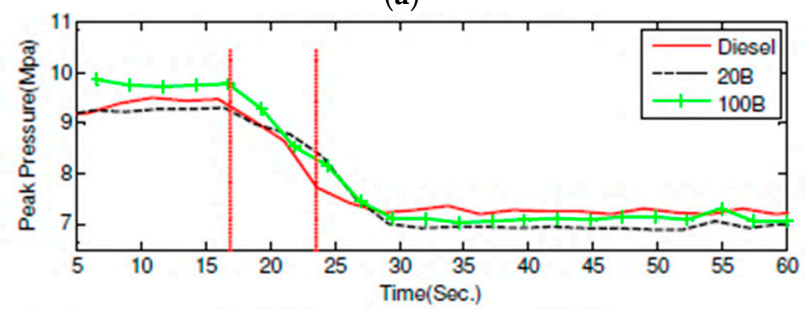

(c)

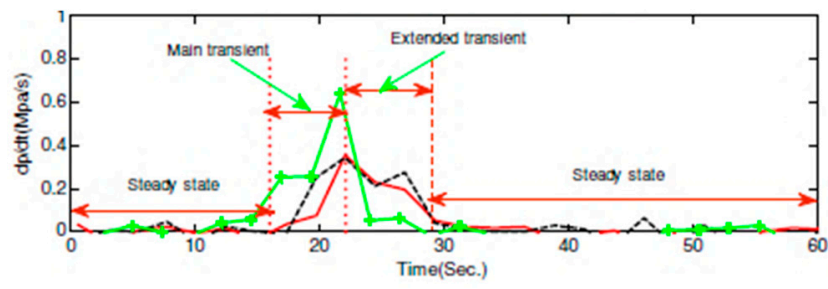

(b)

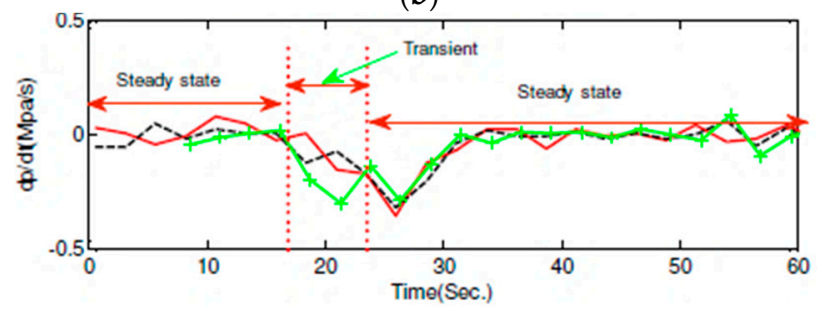

(d)

Figure 8. (a) In-cylinder peak pressure variation for the CI with different fuels during positive torque transient and the (b) corresponding rate of change of in-cylinder peak pressure over time with positive torque transient. (c) In-cylinder peak pressures during negative torque transient; (d) rate of change of in-cylinder peak pressures during negative torque transient.

Shown in Figure 8a is the effect of positive torque transition within the ranges $210 \mathrm{Nm}$ and $420 \mathrm{Nm}$ on the in-cylinder peak pressure when the CI engine was fuelled with diesel, $20 \mathrm{~B}$, and $100 \mathrm{~B}$ at $1500 \mathrm{rpm}$. In pre-transient conditions, the diesel and then $100 \mathrm{~B}$ resulted in a $9 \%$ higher in-cylinder peak pressure. Nevertheless, in post-transient conditions, the engine with $100 \mathrm{~B}$ and $20 \mathrm{~B}$ respectively exhibited $12 \%$ and $6 \%$ higher in-cylinder pressures than the engine fuelled by diesel. Figure $8 \mathrm{~b}$ shows the results of contrasting the transient in-cylinder pressures where the 100B blend resulted in a $45 \%$ higher rate than diesel and 20B. Figure $8 \mathrm{c}$ depicts the in-cylinder peak pressure when the engine is operated with diesel, 20B and 100B $1500 \mathrm{rpm}$ during the negative torque transient of 420-210 Nm. In a similar fashion to the acceleration torque transient, the 100B-run engine resulted in an $8 \%$ higher in-cylinder peak pressure than the diesel pre-transient operation. In post-transient operation, however, fuelled using diesel, the engine produced a higher in-cylinder pressure than with the 100B fuel. In the transient operating conditions, both 20B and 100B gave higher in-cylinder peak pressures. The rate of change of the peak in-cylinder pressure during transient operation for 20B and 100B were lower than that of diesel.

\subsection{Emission Characteristics of CI Engine during Transient Operation}

In this section, the results of detailed investigations carried out on the emission characteristics of the CI engine with diesel and the biodiesel blends are presented. The analysis was performed for four transient operating conditions. These are acceleration, deceleration, negative and positive torque transitions. The analyses were done in three stages. In the first stage, the measured engine emissions characteristics for various operating conditions were compared. In the second stage, the emission release rates of change were computed. Finally, the magnitude of emissions reduction using the biodiesel blends was determined. The major emission compounds studied in the analysis are $\mathrm{CO}_{2}, \mathrm{NOx}, \mathrm{CO}$ and total hydrocarbons (THC). While oxygen $\left(\mathrm{O}_{2}\right)$ was not considered as an emission, its release characteristics under transient conditions were also studied for understanding the combustion phenomena as well as the relationship between the exhaust gas emissions and $\mathrm{O}_{2}$.

\subsubsection{Carbon Dioxide $\left(\mathrm{CO}_{2}\right)$ Emission}

Figure 9 shows $\mathrm{CO}_{2}$ emissions from the engine with diesel and blends $20 \mathrm{~B}$ and $100 \mathrm{~B}$ at a speed transient of $1000 \mathrm{rpm}$ to $1500 \mathrm{rpm}$. The engine load was $420 \mathrm{Nm}$. It is seen that the $\mathrm{CO}_{2}$ emission at $1000 \mathrm{rpm}$ was higher than that at $1500 \mathrm{rpm}$ by $25 \%, 35 \%$ and $5 \%$ for diesel, $20 \mathrm{~B}$ and $100 \mathrm{~B}$ fuels, respectively. All these decreased during acceleration. The reason for the 
decrease is that at higher engine speeds, the fuel/air equivalence ratio of the mix entering the cylinder increased, promoting more complete combustion. To attain the maximum speed, the quantity of fuel required to fully burn in the cylinder increases. Hence, the $\mathrm{CO}_{2}$ emission increases. Figure $9 \mathrm{~b}$ shows the $\mathrm{CO}_{2}$ emission rate during acceleration.

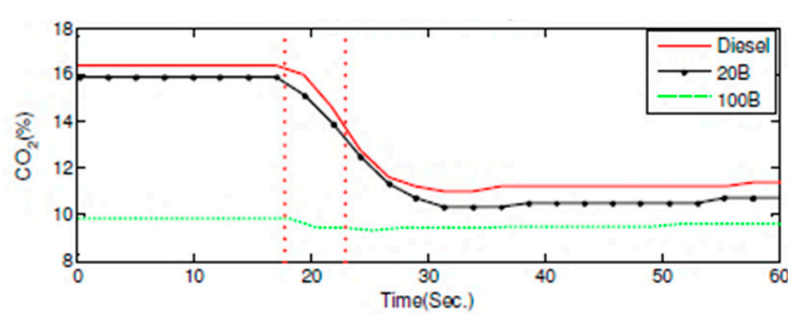

(a)

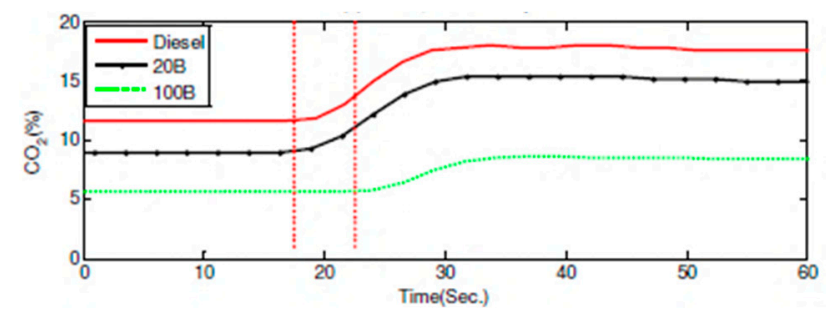

(c)

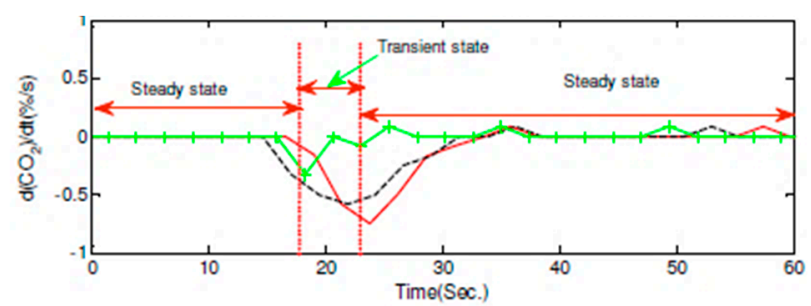

(b)

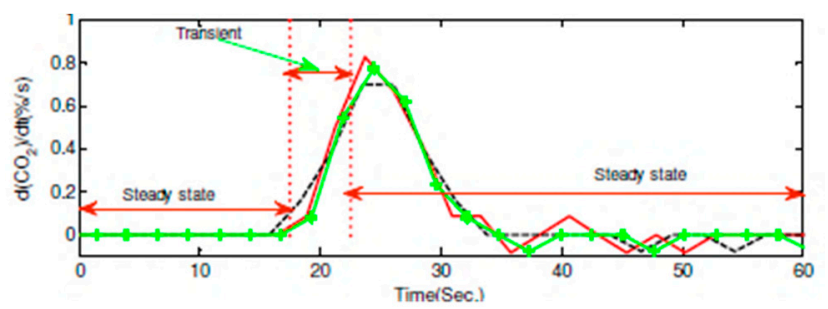

(d)

Figure 9. (a) Time variation of carbon dioxide emission of the $\mathrm{CI}$ engine with the three fuels during positive speed transient at engine load of $420 \mathrm{Nm}$; (b) corresponding rate of change of CO2 emission. (c) Time variation of carbon dioxide emission of the $\mathrm{CI}$ engine during negative speed transient at engine load of $420 \mathrm{Nm}$; (d) corresponding rate of change of CO2 emission at negative speed transient condition.

The emission rates corresponding to diesel and blends 20B and 100B were observed to be irregular. The case with diesel showed the highest rate of change of $0.8 \% / \mathrm{s}$. The $\mathrm{CO}_{2}$ emission transient effects continued for $13 \mathrm{~s}$ after the transient operation was ended. Figure $10 \mathrm{a}, \mathrm{b}$ shows the influence of engine deceleration from 1500 to $1000 \mathrm{rpm}$ on $\mathrm{CO}_{2}$ emissions, during which $\mathrm{CO}_{2}$ emission increased with the engine speed decrease. Figure 10b shows that the rate of change of $\mathrm{CO}_{2}$ emission reached a maximum $1.5 \mathrm{~s}$ after the start of the engine transient and was stable $13 \mathrm{~s}$ after the end of the engine transient. On comparing the $\mathrm{CO}_{2}$ emission rate of change for acceleration (Figure 10b) and deceleration (Figure 10d), we deduce that the former attained a stable condition earlier by $3 \mathrm{~s}$.

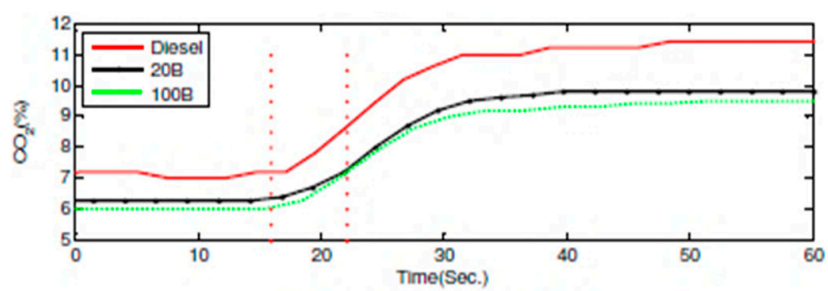

(a)

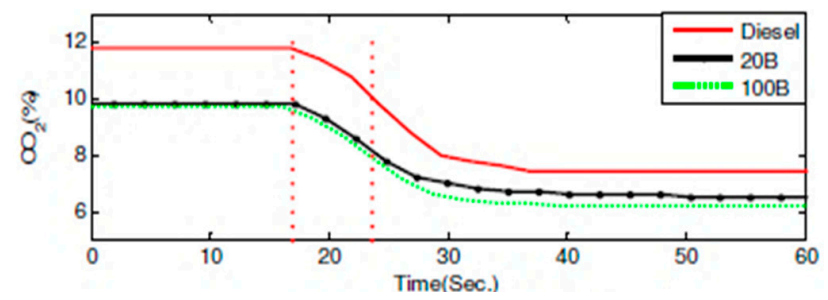

(c)

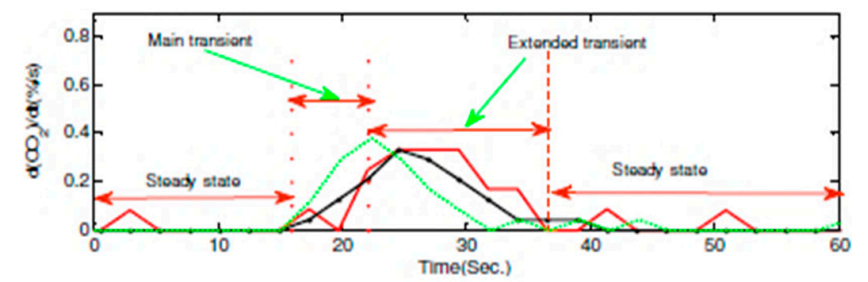

(b)

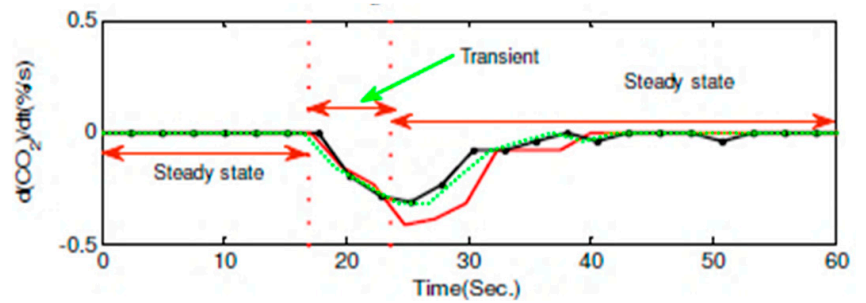

(d)

Figure 10. (a) Variation of $\mathrm{CO}_{2}$ emission in the $\mathrm{CI}$ engine with time with the three fuels during positive torque transient at $1500 \mathrm{rpm}$; (b) rate of change of $\mathrm{CO}_{2}$ emission with time. (c) Variation of $\mathrm{CO} 2$ emission of $\mathrm{CI}$ engines with time during positive torque transient at $1500 \mathrm{rpm}$; (d) corresponding rate of change of $\mathrm{CO}_{2}$ emissions during positive torque transient conditions. 
Figure 10 shows the effect of the torque transition on the diesel-, 20B- and 100B-fuelled engine's parameters. In Figure 10a, the $\mathrm{CO}_{2}$ emission increased with the torque increase from 210 to $420 \mathrm{Nm}$. Figure 10c similarly shows the negative torque transition where the $\mathrm{CO}_{2}$ emission decreased. In both conditions, the engine with the higher torque emitted higher $\mathrm{CO}_{2}$ emissions and may be because there was an increase of the fuel/air equivalence ratio entering the cylinder at the maximum engine load. To produce the maximum torque, the fuel needed to burn completely in the cylinder. This correspondingly produced higher $\mathrm{CO}_{2}$ emissions. Figure $10 \mathrm{~b}-\mathrm{d}$ shows the rates of $\mathrm{CO}_{2}$ emissions to be $0.35 \% / \mathrm{s}$ and $0.30 \% / \mathrm{s}$ for the positive and negative torque transients, respectively. The emission rates for the diesel, 20B and 100B were irregular. During the acceleration and deceleration transients, the $100 \mathrm{~B}$ test case gave higher $\mathrm{CO}_{2}$ emissions.

Four transient conditions were considered: 1000-1500 rpm, 1500-1000 rpm, 210-420 Nm and $420 \mathrm{Nm}-210 \mathrm{Nm}$. Figure 11 shows that for each, the 20B and 100B fuels resulted in lower $\mathrm{CO}_{2}$ emissions than the diesel fuel during both steady and transient operations. It shows the $\mathrm{CO}_{2}$ emission with the two biodiesel blends during acceleration and deceleration at a load of $420 \mathrm{Nm}$. The figure shows that during acceleration, 20B and B100 experienced reduced $\mathrm{CO}_{2}$ emission by $53 \%$ and $122 \%$. Likewise, during deceleration, the $\mathrm{CO}_{2}$ emission with $20 \mathrm{~B}$ and $100 \mathrm{~B}$ reduced by $50 \%$ and $107 \%$, respectively. The maximum reduction in emission was attained during the transient operation in both cases. The carbon dioxide emissions reduction remained rather constant during the pre-transient and post-transient steady-state conditions.

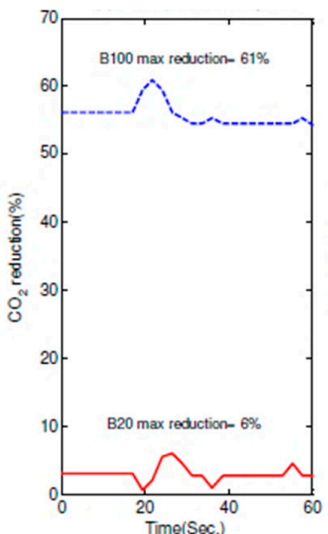

(a)

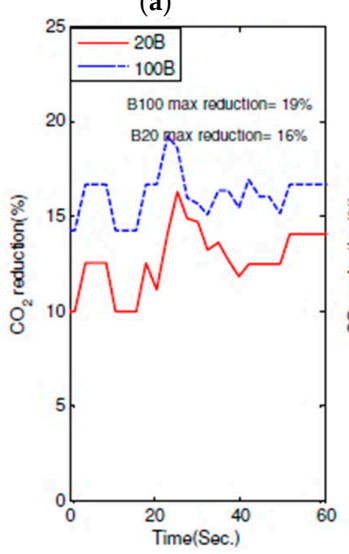

(c)

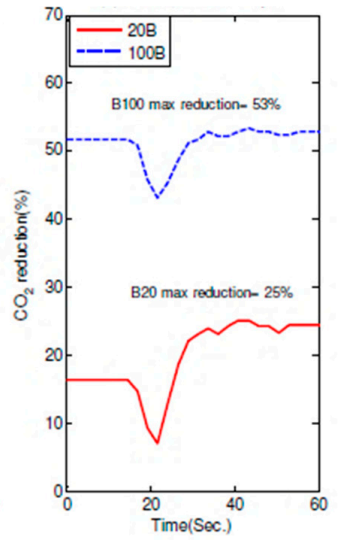

(b)

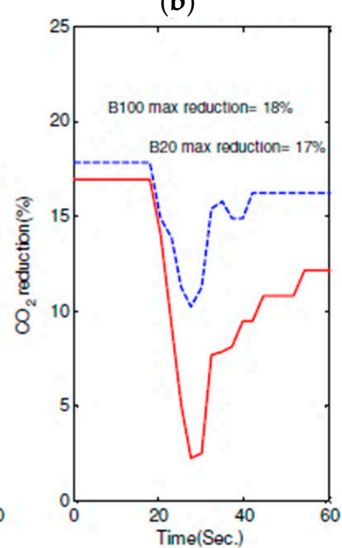

(d)

Figure 11. (a,b)Time trace of percentage $\mathrm{CO}_{2}$ emission reduction using the 20B blend and 100B during the 100-5000 rpm speed transient condition at $420 \mathrm{Nm}$ engine load. $\mathrm{CO}_{2}$ emission percentage reduction of $\mathrm{CI}$ engine with time by using different biodiesel blends at $1500 \mathrm{rpm}$ engine speed for (c) positive and (d) negative torque transition. 
Figure $11 \mathrm{c}$, d represents the $\mathrm{CI}$ engine's $\mathrm{CO}_{2}$ emission reduction during the positive torque transient operation. This caused a non-uniform $\mathrm{CO}_{2}$ emission reduction. Figure 11c shows this inconsistent behaviour. Conversely, the $\mathrm{CO}_{2}$ emission was found to reduce by up to $16 \%$ and $19 \%$, respectively, when the engine was run with the $20 \mathrm{~B}$ blend and $100 \mathrm{~B}$. During the negative torque transition, with the same fuels, the $\mathrm{CO}_{2}$ emission reduced by up to $18 \%$ when compared to diesel. Under the speed transient (1000-1500 rpm) operating conditions investigated, the $\mathrm{CO}_{2}$ emission was maximally reduced due to the lower number of carbon atoms present in biodiesel than in diesel fuel (i.e., biodiesel: $77 \%$ and diesel: $87 \%$ ). Hence, the biodiesel combustion with air gave lower $\mathrm{CO}_{2}$ emissions than diesel does.

\subsubsection{NOx Emission}

Figure 12 shows the effect of biodiesel blends on NOx emission from the $\mathrm{CI}$ engine at a speed transient of 1000-1500 rpm and a load of $420 \mathrm{Nm}$. It reveals fairly constant NOx emission values at pre-transient operation. On the other hand, post-transient, the NOx emission values increased as time progresses. This is because of the increased fuel/air equivalence ratio at higher engine speeds. During high torque and high-speed conditions, fuel is required to burn completely in the cylinder, and this causes higher NOx emissions. Figure $12 \mathrm{~b}$ shows that the NOx emission rates for the speed acceleration are fairly uniform at both pre-transient and post-transient conditions for diesel, 20B and 100B. The rate of change of NOx emission for engine operation with biodiesel was lower than when both 20 $\mathrm{B}$ and diesel were used. The engine run with diesel exhibited the highest rate of change of NOx emissions at $16 \mathrm{ppm} / \mathrm{s}$.

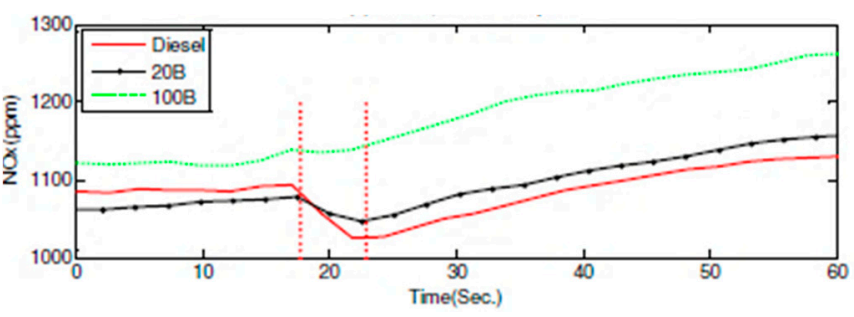

(a)

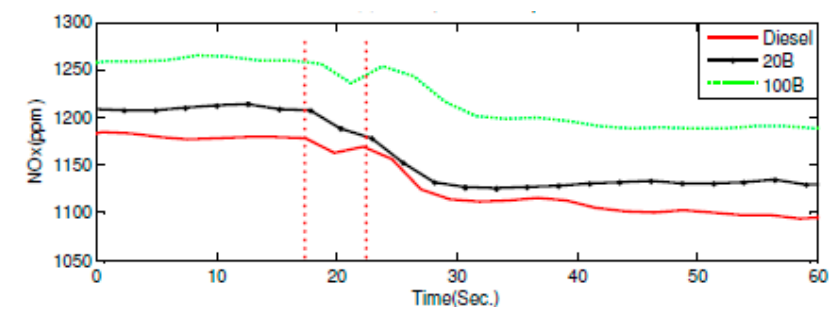

(c)

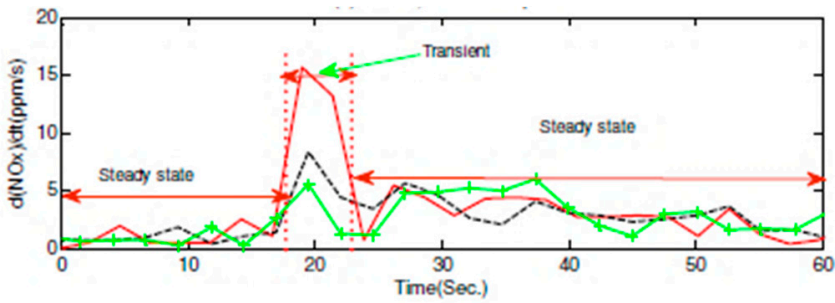

(b)

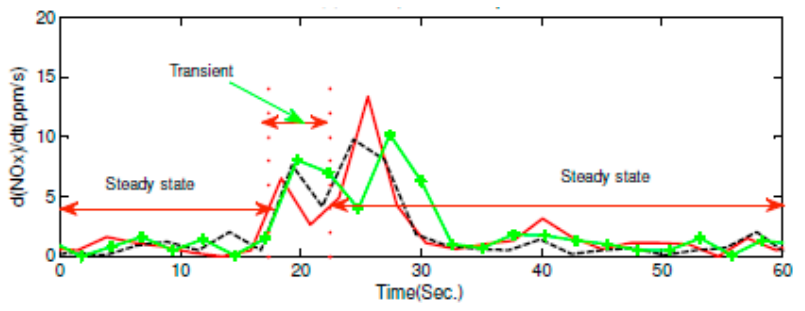

(d)

Figure 12. (a) NOx emission of CI engine over time running with the three fuels during positive speed transient; (b) equivalent rate of change of NOx emission with time. (c) CI engine's NOx emission time variation running with the tested fuels during a negative speed transient; (d) equivalent rate of change of NOx emission during the negative speed transient.

Figure 12c,d depicts the effect of engine deceleration on NOx emission during the 1500-1000 rpm speed transient where the emission increased with the decrease in engine speed. Figure 12c shows that the rate of change of emission with time was nearly zero during pre-transient and post-transient operation. The maximum NOx emission rate was reached $3 \mathrm{~s}$ after the scheduled transient operation. On comparing the NOx acceleration and deceleration emission rates of change, it was found that the former emission rate was higher than the latter during the time range considered. In summary, both acceleration and deceleration resulted in higher NOx emissions for the engine run with 100B.

Figure 13 shows the NOx emission values from the CI engine using diesel, the 20B blend and $100 \mathrm{~B}$ at $1500 \mathrm{rpm}$. These were measured during positive and negative torque 
transitions, respectively. Figure 13a shows that the NOx emission sharply increased with an increase in torque from 210 to $420 \mathrm{Nm}$. Correspondingly, Figure 13 a shows that the NOx emission decreased during the torque transition from 420 to $210 \mathrm{Nm}$. In both cases, the higher torque condition emitted higher NOx emission, and this is because, at the maximum engine load, the input fuel/air equivalence ratio increased. Figure $13 \mathrm{~b}-\mathrm{d}$ shows the rates of change of NOx emission in the positive and negative torque transitions for the three fuels. The 100B fuel resulted in a higher rate of change in NOx emission in both directions of torque transition, with the maximum rate of $95 \%$ for the positive torque and $92 \%$ for the negative torque transient. The pre- and post-transient NOx emission rates were nearly zero for both positive and negative torque transitions. Post-transient, the transition effects on NOx emission were sustained for $10 \mathrm{~s}$ after the transition time.

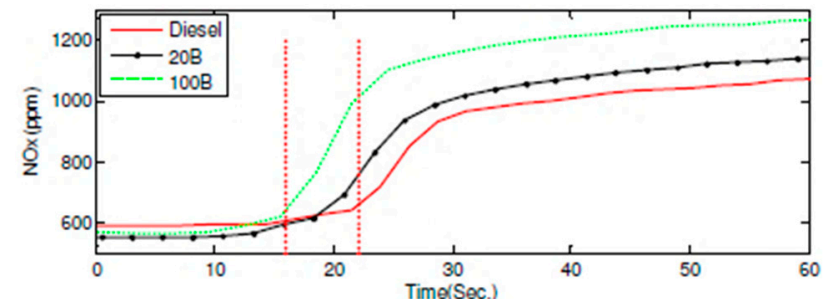

(a)

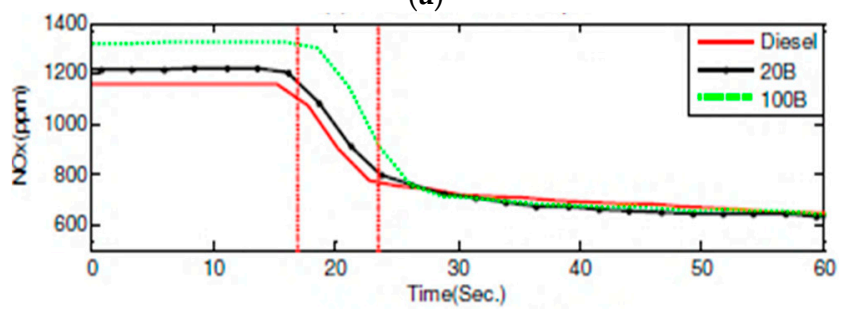

(c)

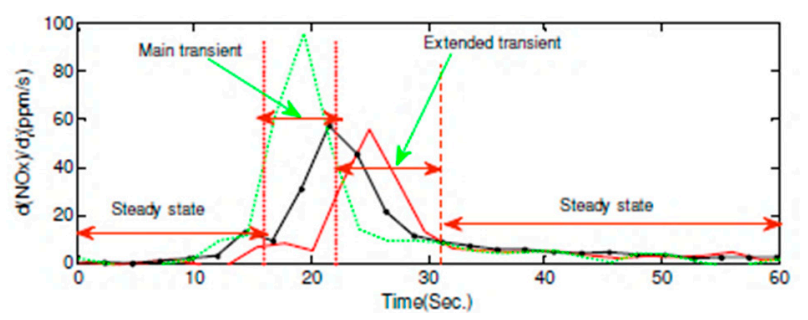

(b)

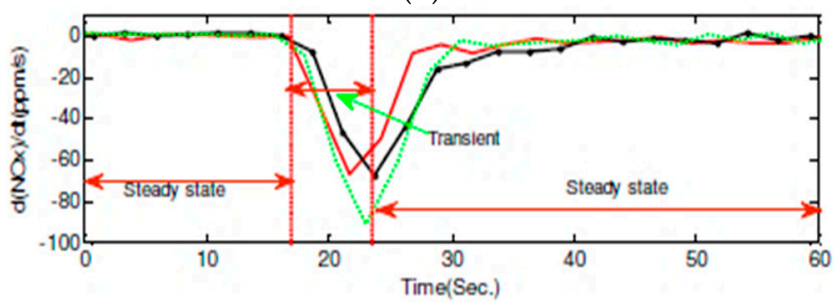

(d)

Figure 13. (a) CI engine's NOx emission time variation running with the tested fuels during a positive speed transient; (b) equivalent rate of change of NOx emission during the positive speed transient. (c) Time variation of NOx emission during a negative torque transient; (d) corresponding rate of change NOx emission during negative torque transient.

Figure 14 shows the NOx emission increase by 20B and 100B over and above the value corresponding to the use of diesel fuel at a constant torque of $420 \mathrm{Nm}$. The values were measured during the 1000-1500 rpm and 1500-1000 rpm acceleration and deceleration, respectively. The NOx emission increased by around 3 and $16 \%$, respectively, in comparison to the engine conditions when running with diesel fuel. Likewise, deceleration also increased the NOx emission by approximately 4 and $8 \%$ for the $20 \mathrm{~B}$ biodiesel blend and 100B, respectively. In Figure 14a, it is seen that the NOx emission sharply increases during the speed transient of 1000-1500 rpm and can be based on the fact that as the engine speed increases, the in-cylinder temperature increased, hence the increase in NOx emissions. Meanwhile, during the deceleration operation, the engine speed reduced, and the incylinder temperature gradually decreased because of the heat transfer, which results in a slow reduction of NOx emission. Figure $14 \mathrm{~b}$ shows the effect of the torque transition on the NOx emission of the engine burning biodiesel at $1500 \mathrm{rpm}$. 


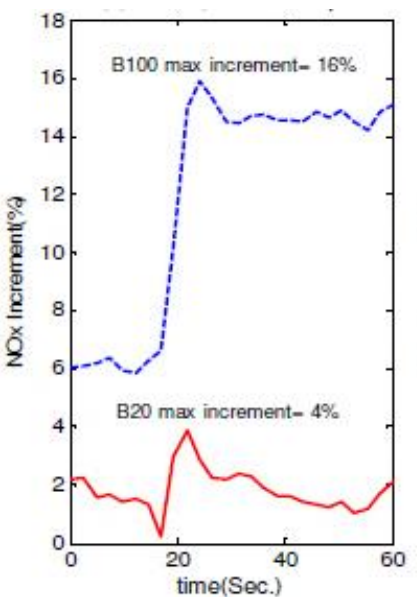

(a)

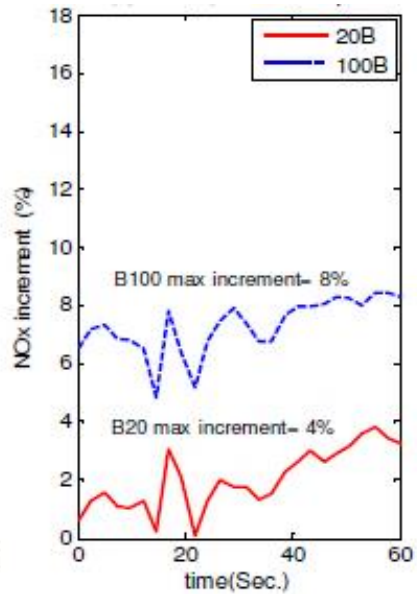

(b)

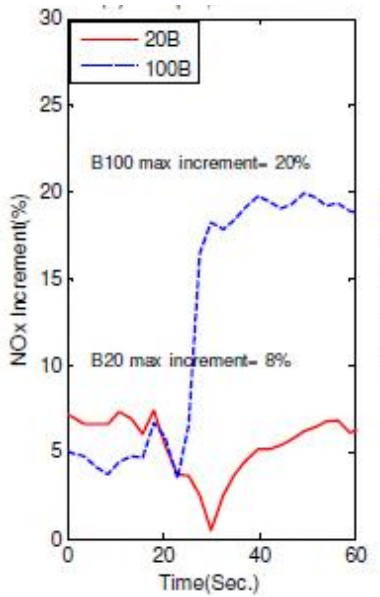

(c)

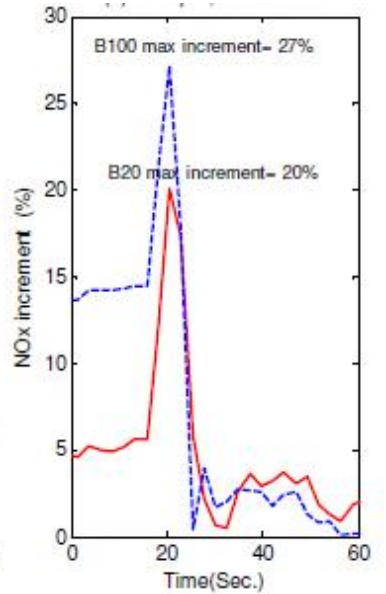

(d)

Figure 14. Variation of NOx emission percentage reduction of CI engine with time with the biodiesel blend fuels during (a) positive and (b) negative speed transients of between 1000 and $1500 \mathrm{rpm}$. Variation of NOx emission percentage reduction in the $\mathrm{CI}$ engine running with the different biodiesel blends during (c) positive and (d) negative torque transient conditions.

The CI engine's NOx emission characteristics running with $20 \mathrm{~B}$ and 100B are shown in Figure 14c. It shows that there was an increase of up to $8 \%$ and $20 \%$, respectively, during the positive torque transient of 210-420 Nm. Likewise, the NOx emission of the engine increased by approximately $20 \%$ for $20 \mathrm{~B}$ and $27 \%$ for $100 \mathrm{~B}$. Biodiesel showed higher NOx emission, and this may because of the advanced combustion process occasioned by its higher viscosity and density. Its lower compressibility characteristics are also a factor. When biodiesel is injected into the engine's cylinder, a rise in pressure occurs due to the pressure energy of the injection pump and due to the lower compressibility and hence higher bulk modulus. This causes quicker propagation towards the injectors. Effectively, the cylinder gas becomes fuel-rich and produces a higher peak temperature that promotes NOx formation.

\subsubsection{Carbon Monoxide (CO) Emission}

Figure 15 shows the CI engine's CO emission at a load of $420 \mathrm{Nm}$. The measurements were carried out at a speed transient of 1000 to $1500 \mathrm{rpm}$. It shows that the engine produces higher $\mathrm{CO}$ emissions during the lower engine speeds. This may be explained on the basis that at lower engine speeds, the temperature of the gases inside the cylinder was lower, which affects $\mathrm{CO}$ conversion to $\mathrm{CO}_{2}$. Figure $15 \mathrm{a}-\mathrm{c}$ shows that the trends of $\mathrm{CO}$ and $\mathrm{CO}_{2}$ emission are opposite. At higher engine speeds, where the air/fuel equivalence ratios increased, there was a rise in the in-cylinder gas temperature. This correspondingly led to an increase in the kinetics or reaction rate of $\mathrm{CO}$ conversion to $\mathrm{CO}_{2}$, hence leading to lower $\mathrm{CO}$ emissions. Figure $15 \mathrm{~b}$ depicts the rate of change of $\mathrm{CO}$ emissions where 20B gave the highest rate of emissions. This is followed by diesel in the transient stage. An extension to the effects of the transient operation occurred well into the post-transient steady conditions. Furthermore, the rate of change of $\mathrm{CO}$ emission extended beyond $16 \mathrm{~s}$ after the transient operation. In summary, the pre- and post-transient $\mathrm{CO}$ emission rate of change was nearly zero, indicating no rise in $\mathrm{CO}$ emission under steady operating conditions. Figure 15c gives the CI engine's CO emission trend with time during speed deceleration from 1500 to $1000 \mathrm{rpm}$. It shows that the engine's CO emission suddenly increased as the engine acceleration increased. Nonetheless, the major effects of the transient operation on $\mathrm{CO}$ emission became apparent after transient operations. Correspondingly, as given in Figure 15d, the transient effects continued for $18 \mathrm{~s}$ after the transient operation with diesel and 20B, producing maximum $\mathrm{CO}$ emission rates of approximately $110 \mathrm{ppm} / \mathrm{s}$. 


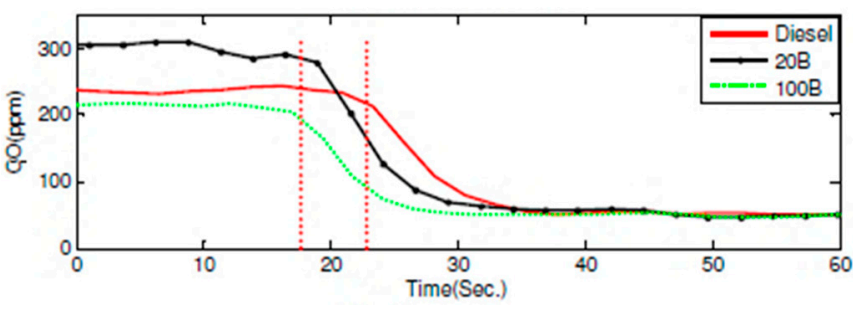

(a)

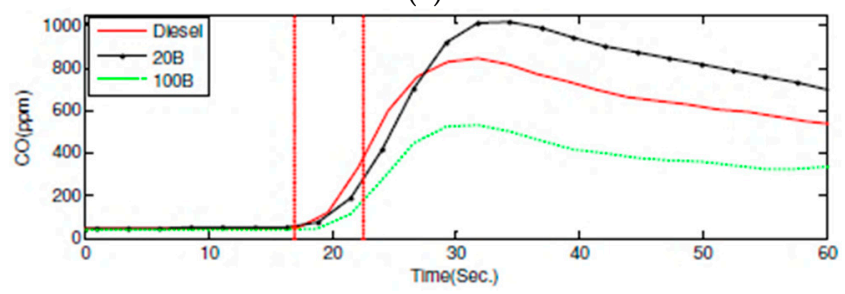

(c)

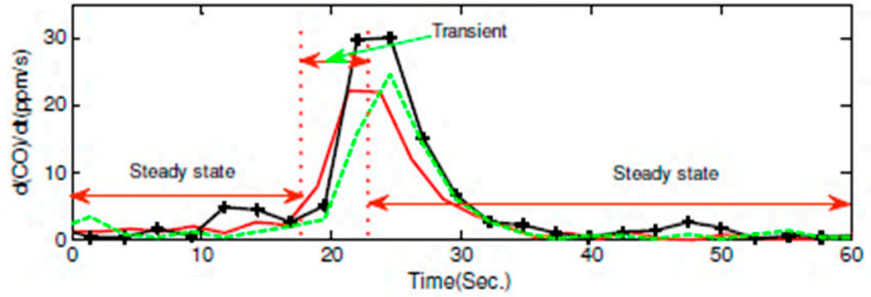

(b)

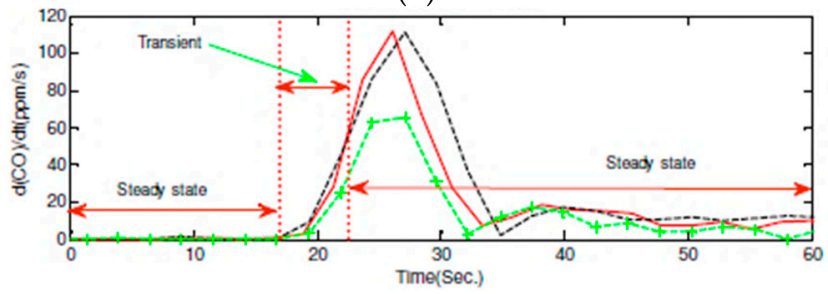

(d)

Figure 15. (a) Positive speed transient emission characteristics of $\mathrm{CO}$ in the $\mathrm{CI}$ engine running with the three fuels during positive speed transient; (b) corresponding rate of change of $\mathrm{CO}$ emission. (c) $\mathrm{CO}$ emission characteristics in $\mathrm{CI}$ engine running with the three fuels during negative speed transient; (d) corresponding rate of change of CO emission.

Figure 16 shows the effects of torque transition at $1500 \mathrm{rpm}$ on $\mathrm{CO}$ emission of the engine running with diesel, 20B and 100B fuels. Figures 16a and 17a show that the torque transients had no significant effects on $\mathrm{CO}$ emission at both positive and negative transients. In both transient directions, the emission rate varied between 0 and $3 \mathrm{ppm} / \mathrm{s}$. These are as indicated in Figures $16 \mathrm{~b}$ and $17 \mathrm{~b}$ where the maximum $\mathrm{CO}$ emission rate was $3 \mathrm{ppm} / \mathrm{s}$ during both transients.

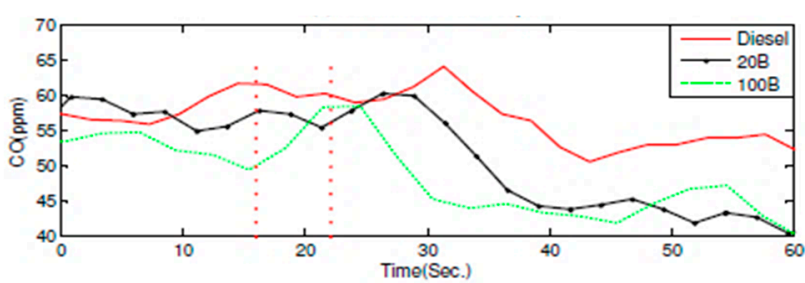

(a)

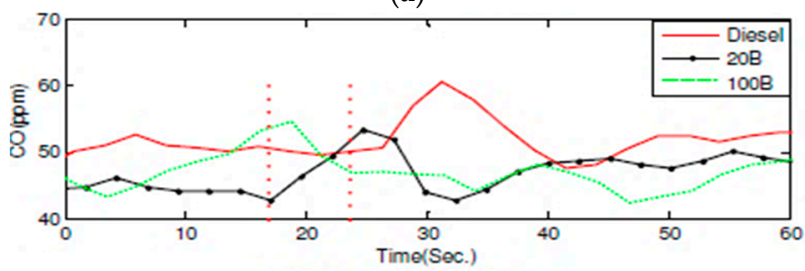

(c)

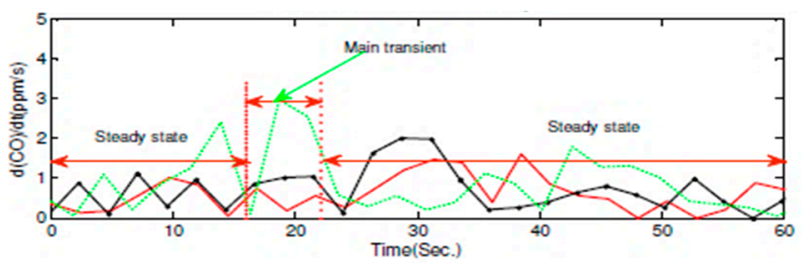

(b)

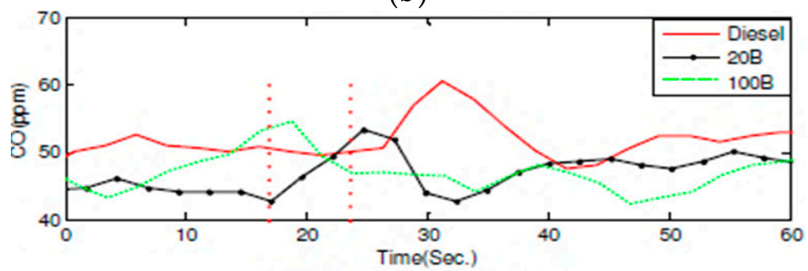

(d)

Figure 16. (a) Engine $\mathrm{CO}$ emission running with the three fuels during positive torque transient at $1500 \mathrm{rpm}$; (b) corresponding rate of change of $\mathrm{CO}$ emission at the same conditions. (c) Variation of CO emission of CI engines with time for running with different fuels during the negative torque transient of 420 to $210 \mathrm{Nm}$ at $1500 \mathrm{rpm}$; (d) rate of change of CO emission under the same conditions.

Figure 17 indicates the influence of the biodiesel blend on the CI engine's CO emission at speed and torque transients. During the speed transition condition, the engine running with 20B and 100B gave a decrease in CO emissions by up to 39 and $45 \%$, respectively. During deceleration, the peak increases of $122 \%$ and $124 \%$ in CO emissions were attained for $20 \mathrm{~B}$ and 100B, respectively. Consequently, Figure 19 shows the effect of fuel on CO emission at an engine speed of $1500 \mathrm{rpm}$ during the torque transient. It is clear from the 
figure that the engine's CO emission with $20 \mathrm{~B}$ and $100 \mathrm{~B}$ reduced by $22 \%$ and $24 \%$ for positive torque transition, and $18 \%$ and $22 \%$ for negative torque transition, respectively.

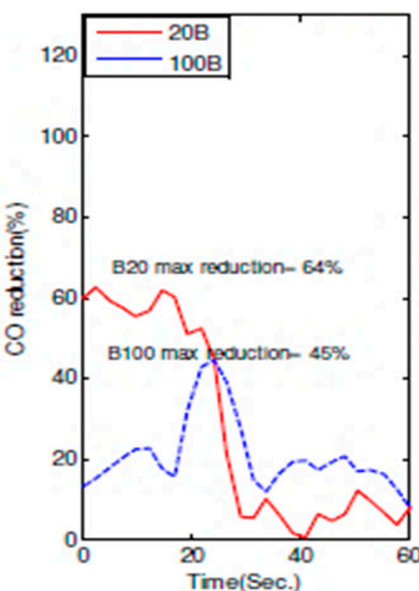

(a)

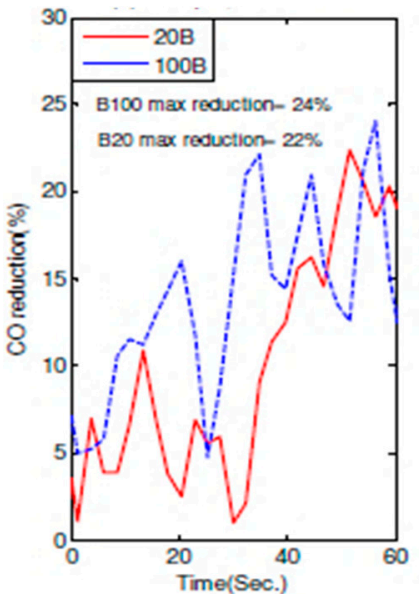

(c)

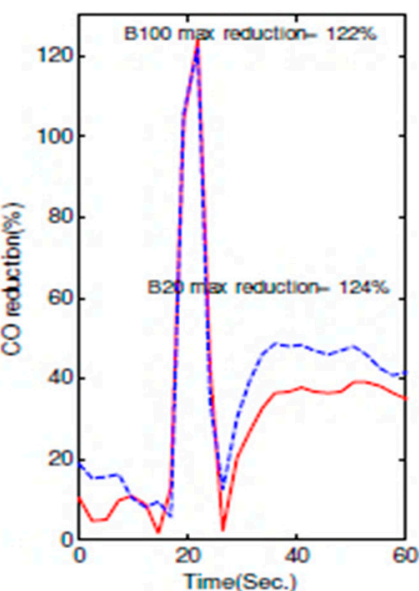

(b)

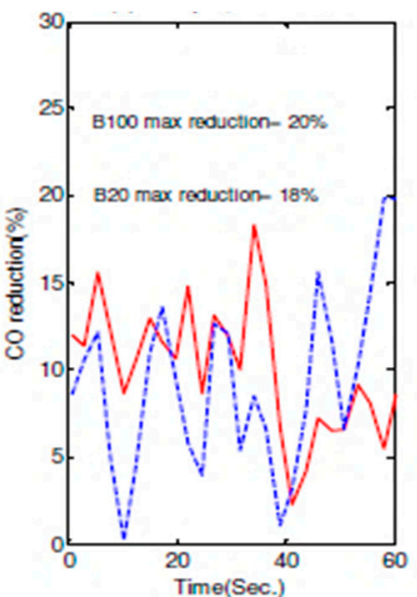

(d)

Figure 17. Time variation of percentage $\mathrm{CO}$ emissions reduction in the engine running $20 \mathrm{~B}$ and $100 \mathrm{~B}$ during the (a) positive and (b) negative speed transient at a torque of $420 \mathrm{Nm}$. Percentage CO emission reduction over time with $20 \mathrm{~B}$ and $100 \mathrm{~B}$ at $1500 \mathrm{rpm}$ during the (c) positive and (d) negative torque transient.

\subsubsection{Total Hydrocarbon (THC) Emissions}

Figure 18 shows the total hydrocarbon (THC) emission of the CI engine running with $20 \mathrm{~B}$ and 100B. The engine load was $420 \mathrm{Nm}$ and the speed transient was 1000-1500 rpm. The THC emission was shown to decrease during the engine acceleration operation. The figure shows that when the engine was run with 100B, the THC emissions were higher than for diesel and 20B under transient conditions. Furthermore, the pre- and post-transient rates of change of THC emissions were below $0.1 \% / \mathrm{s}$. It is noted that the transient operation did not significantly affect the post-transient steady operations. Figure 18a shows acceleration effects on THC emissions of the $\mathrm{CI}$ engine. It indicates a sharp THC emission increase with decreasing engine speed. Figure 18d shows that when run with diesel, the emissions rate was highest and was followed by 20B. Conversely, the pre- and post-transient emission rates were nearly zero, while the transient operation had an insignificant effect on the preceding steady operation under increased speed transient operation from 1000 to $1500 \mathrm{rpm}$. 


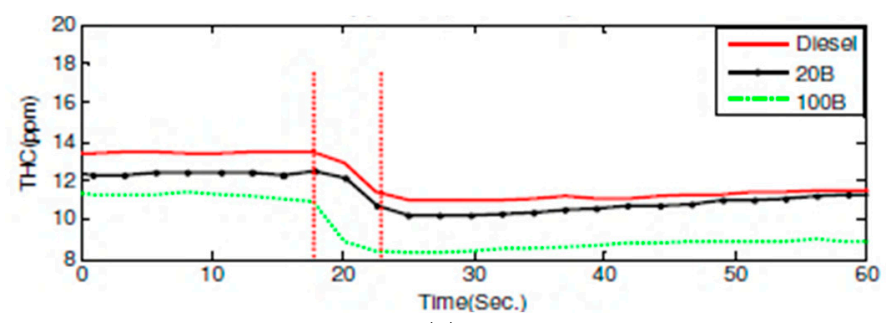

(a)

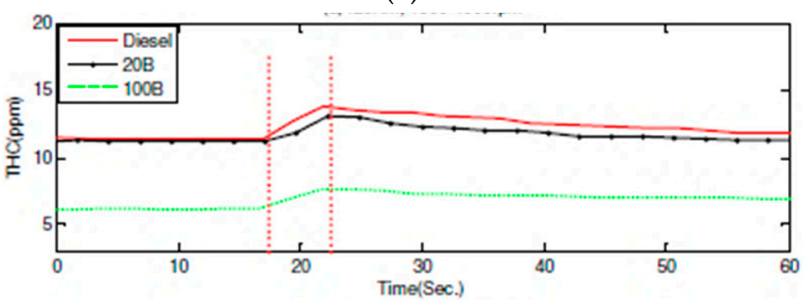

(c)

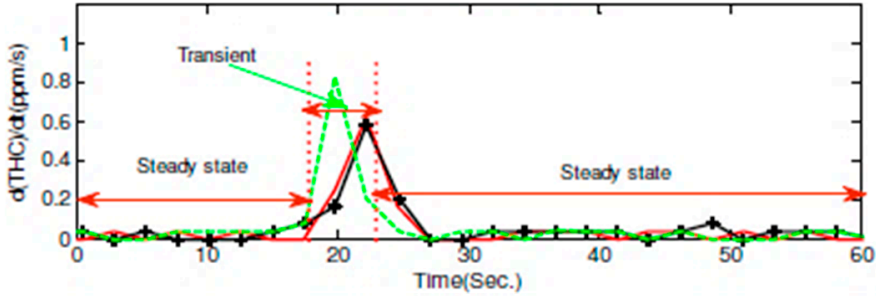

(b)

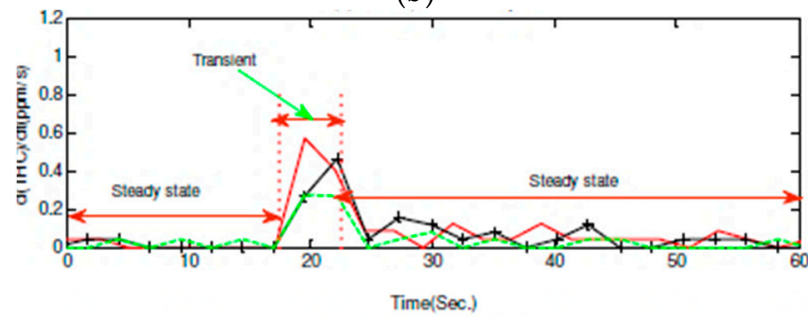

(d)

Figure 18. (a) THC emission in the engine with the three fuels during the negative speed transient at a torque of $420 \mathrm{Nm}$; (b) corresponding rate of change of THC emission. (c) THC emission in the engine with the three fuels during the positive speed transient at a torque of $420 \mathrm{Nm}$; (d) corresponding rate of change of THC emission.

Figure 19 shows the influence of torque transition on THC emission with the engine running with the three fuels at $1500 \mathrm{rpm}$. Figure 19a shows that the THC experienced a decrease as the torque increases from 210 to $420 \mathrm{Nm}$ for the three fuels studied. As indicated by Figure $19 b-d$, the emission rates during positive and negative torque transitions varied between -0.5 and $0.5 \mathrm{ppm} / \mathrm{s}$, and in both cases, the 100B THC emission rate progressed towards zero.
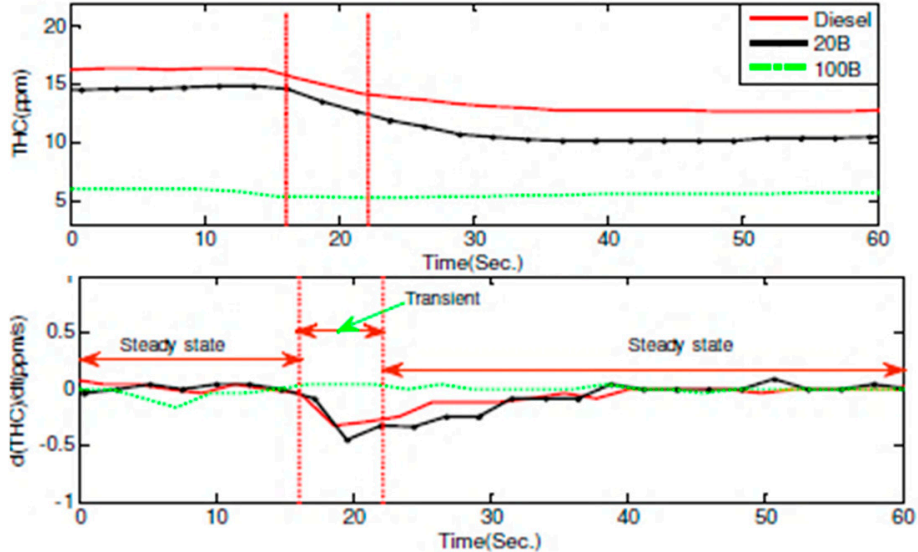

(a)
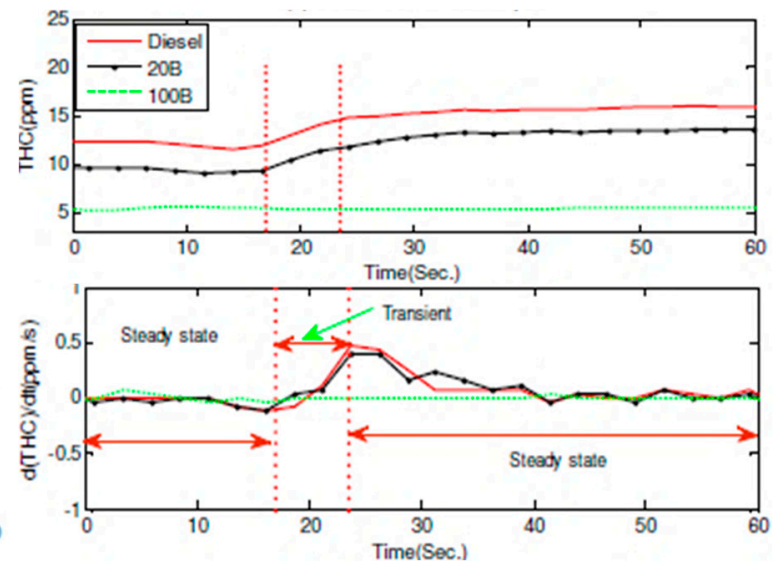

(b)

Figure 19. (a) Top: Time variation of THC emission with the three fuels during positive torque at $1500 \mathrm{rpm}$; bottom: Attendant rate of change of THC emission (b) Top: THC emission in the CI engine running with biodiesel, 2B and 100B fuels during negative torque transient at $1500 \mathrm{rpm}$; bottom: Corresponding rate of change of THC emissions.

The total hydrocarbon emissions of the 20B biodiesel blend and 100B for the positive speed transient (1000-1500 rpm) are shown in Figure 20. In addition, biodiesel has a higher cetane number and this reduces the combustion delay by approximately $33 \%$ and $45 \%$ for $2 \mathrm{~B}$ and by $9 \%$ and $48 \%$ for 100B. In a similar fashion, the THC was reduced by up to $21 \%$ and $63 \%$ and $28 \%$ and $66 \%$ during the torque transition operation, when using biodiesel blends of 25B and 100B, respectively, as it is depicted in Figure 20c,d. The reduction in THC could be because the biodiesel has a chemical composition with $11 \%$ oxygen, and this has two major effects, namely reduction of the number of carbon and hydrogen atoms 
that enter the cylinder and the complete combustion being guaranteed by the presence of oxygen atoms.

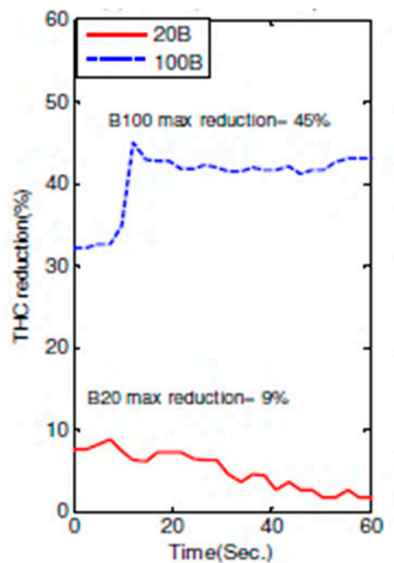

(a)

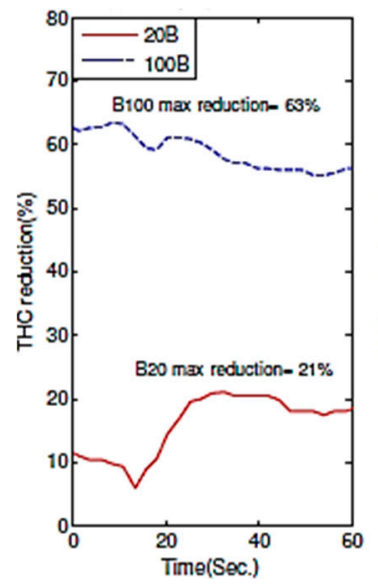

(c)

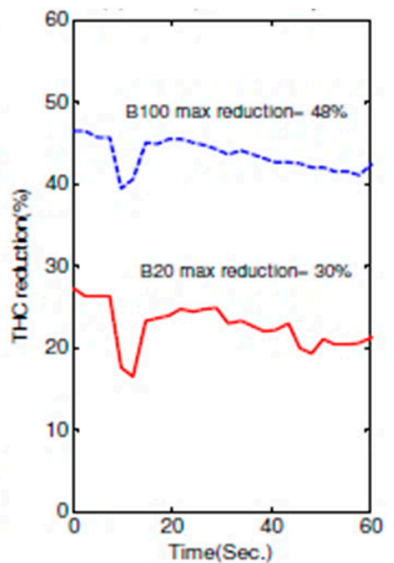

(b)

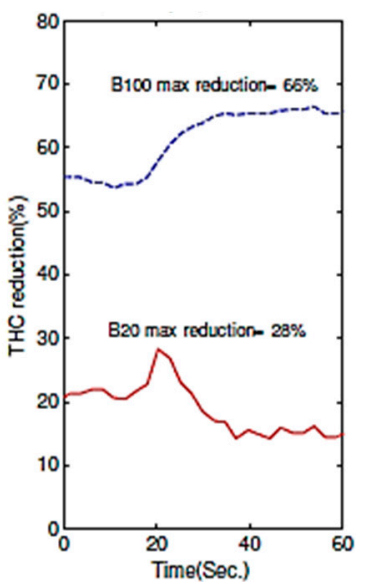

(d)

Figure 20. Percent reduction in THC emissions in the CI engine running with 20B blend and 100B during (a) positive and (b) negative speed transient conditions at $420 \mathrm{Nm}$ torque. Percentage of THC emission reduction of the $\mathrm{CI}$ engine at (c) positive and (d) negative torque transition conditions at a constant engine speed of $1500 \mathrm{rpm}$.

\section{Conclusions}

Given the global concerns on the effect of emissions due to fossil fuels on the environment, the use of petroleum-based fuels is experiencing serious re-examination. Alternatives to these are biofuels, which are foreseen to complement electric fuels especially for longhaul heavy-goods transport. This paper examined the performance and emission characteristics of a compression injection (CI) engine with diesel, a 20\% biodiesel-diesel blend (i.e., 20B) and 100\% biodiesel (100B) under various transient operating conditions. It was found that the performance of $\mathrm{CI}$ engines during transient operations can vary significantly from steady operation depending on whether diesel or biodiesel is used. Experiments were carried out on a direct injection, 4-stroke, CI engine at the University of Huddersfield. Data analysis was performed to compare the fuel flow rate, the exhaust gas temperature, the in-cylinder pressure and the nature of engine emissions $\left(\mathrm{CO}_{2}, \mathrm{NOx}, \mathrm{CO}\right.$ and THC) under speed and torque transients. Several important conclusions were drawn from the engine's performance and emission characteristics during the various transient operations. Firstly, we found that the 100B fuel flow rate was higher than that of diesel by $16 \%$ and $14 \%$ for the acceleration and deceleration transient operations, respectively, under the same positive and negative speed transient operating conditions. Furthermore, the flow rate values increased to $17 \%$ and $15 \%$, respectively, for positive and negative torque transient 
conditions. We found that during engine acceleration and deceleration, the maximum difference between the exhaust temperature with diesel and each of the biodiesels and the $20 \mathrm{~B}$ blend is less than $2 \%$. Conversely, at torque transients, running with biodiesel produces higher exhaust gas temperatures than that of running with diesel, by at least $7 \%$. The influence of fuel type on engine emissions is significant as we found that lower $\mathrm{CO}_{2}$, $\mathrm{CO}$ and THC emission results when biodiesel is used during all the transient operations. However, using biodiesel as a fuel in the engine results in an increase in NOx emissions during both speed and torque transition conditions. Finally, we deduced that the influence of transient operations on emissions are not limited to the transient operation period but are propagated far beyond torque and speed transient condition and can continue for up to 20 s post-transient. Furthermore, the post-transient emission time span of NOx and $\mathrm{CO}$ is higher than those of the other emissions. This is due to the relationship between NOx emission and the nature of thermal production and dissipation during combustion within the engine's cylinder. After the instant transient operations, the conditions within the cylinder change and these take a long time to stabilise due to the unsteady convection and conduction heat transfer processes in the cylinder. In conclusion, we have established that the performance of CI engines with biodiesel blends do not differ significantly when compared with conventional diesel. For example, there was less than $5 \%$ difference between the fuels in the peak engine pressure. Conversely, there is a marked decrease in Nox, CO and THC emissions. CO emission decreased by $25 \%$ and $50 \%$, respectively, for the B20 blend and B100, respectively. This further underlines the importance of moving from petrol-based to biodiesel for heavy-goods vehicles, for example, without modifying current engines. As a recommendation for future work, the effect of other biodiesel blends need to be carried out over a wider range of torque and speed transients than have been investigated in this paper.

Author Contributions: Conceptualization: R.M. and B.C.T.; methodology R.M. and B.C.T.; software and experimentation B.C.T.; formal analysis, B.C.T.; data curation B.C.T.; writing-original draft preparation, B.C.T.; writing-review and editing, B.C.T., R.M. and A.M.A.; supervision, R.M. All authors have read and agreed to the published version of the manuscript.

Funding: This research received no external funding.

Data Availability Statement: The data in this paper can be made available upon reasonable request.

Conflicts of Interest: The authors declare no conflict of interest.

\section{References}

1. Patel, A.; Arora, N.; Sartaj, K.; Pruthi, V.; Pruthi, P.A. Sustainable biodiesel production from oleaginous yeasts utilizing hydrolysates of various non-edible lignocellulosic biomasses. Renew. Sustain. Energy Rev. 2016, 62, 836-855. [CrossRef]

2. Nguyen, T.; Khoa, N.; Tuan, L. The Correlation of Biodiesel Blends with the Common Rail Diesel Engine's Performance and Emission Characteristics. Energies 2021, 14, 2986. [CrossRef]

3. Alptekin, E.; Canakci, M. Determination of the density and the viscosities of biodiesel-diesel fuel blends. Renew. Energy 2008, 33, 2623-2630. [CrossRef]

4. Tate, R.; Watts, K.; Allen, C.; Wilkie, K. The viscosities of three biodiesel fuels at temperatures up to $300{ }^{\circ} \mathrm{C}$. Fuel 2006, 85 , 1010-1015. [CrossRef]

5. Tate, R.; Watts, K.; Allen, C.; Wilkie, K. The densities of three biodiesel fuels at temperatures up to $300{ }^{\circ} \mathrm{C}$. Fuel 2006, $85,1004-1009$. [CrossRef]

6. Freedman, B.; Bagby, M.O. Heats of combustion of fatty esters and triglycerides. J. Am. Oil Chem. Soc. 1989, 66, 1601-1605. [CrossRef]

7. Yamane, K.; Ueta, A.; Shimamaoto, Y. Influence of physical and chemical properties of biodiesel fuels on injection, combustion and exhaust emission characteristics in a direct injection compression ignition engine. Int. Res. J. 2001, 2. [CrossRef]

8. Gumus, M. A comprehensive experimental investigation of combustion and heat release characteristics of a biodiesel (hazelnut kernel oil methyl ester) fueled direct injection compression ignition engine. Fuel 2010, 89, 2802-2814. [CrossRef]

9. Benjumea, P.; Agudelo, J.; Agudelo, A. Effect of altitude and palm oil biodiesel fuelling on the performance and combustion characteristics of a HSDI diesel engine. Fuel 2009, 88, 725-731. [CrossRef]

10. Gao, Y.; Deng, J.; Li, C.; Dang, F.; Liao, Z.; Wu, Z.; Li, L. Experimental study of the spray characteristics of biodiesel based on inedible oil. Biotechnol. Adv. 2009, 27, 616-624. [CrossRef] [PubMed] 
11. Kegl, B.; Hribernik, A. Experimental Analysis of Injection Characteristics Using Biodiesel Fuel. Energy Fuels 2006, 20 , $2239-2248$. [CrossRef]

12. Bannikov, M.G.; Tyrlovoy, S.I.; Vasilev, I.P.; Chattha, J.A. Investigation of the Characteristics of the Fuel Injection Pump of a Diesel Engine Fuelled with Viscous Vegetable Oil-Diesel Oil Blends. Proc. Inst. Mech. Eng. Part D J. Automob. Eng. 2006, 220 , 787-792. [CrossRef]

13. Soudagar, M.E.M.; Mujtaba, M.; RezaSafaeibcd, M.; Afzale, A.; V, D.R.; Ahmeda, W.; Banapurmath, N.; Hossainh, N.; Bashiri, S.; AnjumBadruddinjk, I.; et al. Effect of Sr@ZnO nanoparticles and Ricinus communis biodiesel-diesel fuel blends on modified CRDI diesel engine characteristics. Energy 2021, 215, 119094. [CrossRef]

14. Khan, H.; Soudagar, M.E.M.; Kumar, R.H.; Safaei, M.R.; Farooq, M.; Khidmatgar, A.; Banapurmath, N.R.; Farade, R.A.; Abbas, M.M.; Afzal, A.; et al. Effect of Nano-Graphene Oxide and n-Butanol Fuel Additives Blended with Diesel—Nigella sativa Biodiesel Fuel Emulsion on Diesel Engine Characteristics. Symmetry 2020, 12, 961. [CrossRef]

15. Szybist, J.; Song, J.; Alam, M.; Boehman, A.L. Biodiesel combustion, emissions and emission control. Fuel Process. Technol. 2007, 88, 679-691. [CrossRef]

16. Yusuf, A.; Hanna, M.A. In-Cylinder Pressure Characteristics of a D.I. Heavy Duty Diesel Engine on Biodiesel Fuel. SAE 1997, 971683. [CrossRef]

17. Monyem, A.; Van Gerpen, J.H. The effect of biodiesel oxidation on engine performance and emissions. Biomass-Bioenergy 2001, 20, 317-325. [CrossRef]

18. Martyr, A.J.; Plint, M.A. Engine Testing: Theory and Practice, 3rd ed.; A Butterworth-Heinemann Title: Oxford, UK, 2007.

19. Abu-Qudais, M. Exhaust gas temperature for knock detection and control in spark ignition engine. Energy Convers. Manag. 1996, 37, 1383-1392. [CrossRef]

20. Morey, F.; Seers, P. Comparison of cycle-by-cycle variation of measured exhaust-gas temperature and in-cylinder pressure measurements. Appl. Therm. Eng. 2010, 30, 487-491. [CrossRef]

21. Hountalas, D.T.; Mavropoulos, G.; Zannis, T.C.; Mamalis, S.D. Use of Water Emulsion and Intake Water Injection as NOx Reduction Techniques for Heavy Duty Diesel Engines. In SAE Technical Paper Series; SAE International: Warrendale, PA, USA, 2006.

22. Al-Shemmeri, T.; Oberweis, S. Correlation of the NOx emission and exhaust gas temperature for biodiesel. Appl. Therm. Eng. 2011, 31, 1682-1688. [CrossRef]

23. Abu-Zaid, M. Performance of single cylinder, direct injection Diesel engine using water fuel emulsions. Energy Convers. Manag. 2004, 45, 697-705. [CrossRef]

24. Lin, C.-Y.; Lin, H.-A. Diesel engine performance and emission characteristics of biodiesel produced by the peroxidation process. Fuel 2006, 85, 298-305. [CrossRef]

25. Lin, C.-Y.; Wang, K.-H. Diesel engine performance and emission characteristics using three-phase emulsions as fuel. Fuel 2004, 83, 537-545. [CrossRef]

26. Ramadhas, A.; Muraleedharan, C.; Jayaraj, S. Performance and emission evaluation of a diesel engine fueled with methyl esters of rubber seed oil. Renew. Energy 2005, 30, 1789-1800. [CrossRef]

27. Carraretto, C.; Macor, A.; Mirandola, A.; Stoppato, A.; Tonon, S. Biodiesel as alternative fuel: Experimental analysis and energetic evaluations. Energy 2004, 29, 2195-2211. [CrossRef]

28. Raheman, H.; Phadatare, A. Diesel engine emissions and performance from blends of karanja methyl ester and diesel. BiomassBioenergy 2004, 27, 393-397. [CrossRef]

29. Meng, X.; Chen, G.; Wang, Y. Biodiesel production from waste cooking oil via alkali catalyst and its engine test. Fuel Process. Technol. 2008, 89, 851-857. [CrossRef]

30. Labeckas, G.; Slavinskas, S. The effect of rapeseed oil methyl ester on direct injection Diesel engine performance and exhaust emissions. Energy Convers. Manag. 2006, 47, 1954-1967. [CrossRef]

31. Qi, D.; Geng, L.; Chen, H.; Bian, Y.; Liu, J.; Ren, X. Combustion and performance evaluation of a diesel engine fueled with biodiesel produced from soybean crude oil. Renew. Energy 2009, 34, 2706-2713. [CrossRef]

32. Lapuerta, M.; Armas, O.; Fernández, J.R. Effect of biodiesel fuels on diesel engine emissions. Prog. Energy Combust. Sci. 2008, 34, 198-223. [CrossRef]

33. Tesfa, B.; Mishra, R.; Gu, F.; Powles, N. Prediction models for density and viscosity of biodiesel and their effects on fuel supply system in CI engines. Renew. Energy 2010, 35, 2752-2760. [CrossRef]

34. Tesfa, B.; Mishra, R.; Gu, F.; Ball, A. Water injection effects on the performance and emission characteristics of a CI engine operating with biodiesel. Renew. Energy 2012, 37, 333-344. [CrossRef]

35. Tesfa, C.B.; Mishra, R.; Zhang, C.; Gu, F.; Ball, A.D. Commbustion and performance characteristics of CI (compression ignition) engine running with biodiesel. Energy 2013, 51, 101-115. [CrossRef]

36. Tesfa, B.; Gu, F.; Mishra, R.; Ball, A. LHV predication models and LHV effect on the performance of CI engine running with biodiesel blends. Energy Convers. Manag. 2013, 71, 217-226. [CrossRef] 